\title{
Resistance to Fusarium Head Blight, Kernel Damage, and Concentration of Fusarium Mycotoxins in Grain of Winter Triticale (x Triticosecale Wittmack) Lines
}

\author{
Tomasz Góral ${ }^{1, *(D)}$, Halina Wiśniewska ${ }^{2, *}$, Piotr Ochodzki ${ }^{1}$, Adriana Twardawska ${ }^{2}$ and Dorota Walentyn-Góral ${ }^{1}$ \\ 1 Department of Plant Pathology, Plant Breeding and Acclimatization Institute-National Research Institute, \\ Radzików, 05-870 Błonie, Poland; p.ochodzki@ihar.edu.pl (P.O.); d.walentyn-goral@ihar.edu.pl (D.W.-G.) \\ 2 Institute of Plant Genetics, Polish Academy of Sciences, 34 Strzeszyńska Str., 60-479 Poznań, Poland; \\ atwa@igr.poznan.pl \\ * Correspondence: t.goral@ihar.edu.pl (T.G.); hwis@igr.poznan.pl (H.W.); Tel.: +48-22-733-4636 (T.G.)
}

Citation: Góral, T.; Wiśniewska, H.; Ochodzki, P.; Twardawska, A.; Walentyn-Góral, D. Resistance to Fusarium Head Blight, Kernel Damage, and Concentration of Fusarium Mycotoxins in Grain of Winter Triticale (x Triticosecale Wittmack) Lines. Agronomy 2021, 11, 16. https: / / dx.doi.org/10.3390/ agronomy11010016

Received: 2 November 2020 Accepted: 19 December 2020 Published: 23 December 2020

Publisher's Note: MDPI stays neutral with regard to jurisdictional claims in published maps and institutional affiliations.

Copyright: () 2020 by the authors. Licensee MDPI, Basel, Switzerland. This article is an open access article distributed under the terms and conditions of the Creative Commons Attribution (CC BY) license (https: / / creativecommons.org/ licenses/by/4.0/).

\begin{abstract}
Fusarium head blight (FHB) can cause contamination of cereal grain with mycotoxins. Triticale is also infected with FHB; however, it is more resistant than wheat to head infection. The aim of this study was to identify triticale lines that combine low head infection with low toxin contamination. Resistance to FHB of 15 winter triticale and three winter wheat lines was evaluated over a three-year experiment established in two locations. At the anthesis stage, heads were inoculated with Fusarium culmorum isolates. The FHB index was scored and the percentage of Fusarium-damaged kernels (FDKs) assessed. The grain was analysed for type B trichothecenes (deoxynivalenol and derivatives, nivalenol) and zearalenone content. The average FHB index was $10.7 \%$. The proportion of FDK was $18.1 \%$ (weight) and $21.6 \%$ (number). An average content of deoxynivalenol amounted to $7.258 \mathrm{mg} / \mathrm{kg}$ and nivalenol to $5.267 \mathrm{mg} / \mathrm{kg}$. In total, it was $12.788 \mathrm{mg} / \mathrm{kg}$ of type B trichothecenes. The zearalenone content in the grain was $0.805 \mathrm{mg} / \mathrm{kg}$. Relationships between FHB index, FDK, and mycotoxin contents were statistically significant for triticale lines; however, they were stronger for FDK versus mycotoxins. Triticale lines combing all types of FHB resistance were found, however the most resistant ones were less resistant that wheat lines with the $F h b 1$ gene.
\end{abstract}

Keywords: deoxynivalenol; Fusarium culmorum; Fusarium head blight; nivalenol; triticale; trichothecenes; zearalenone

\section{Introduction}

Triticale (x Triticosecale Wittmack) is the first synthetic successful amphiploid cereal, which originated in 1874, from hybridization of hexaploid wheat (Triticum aestioum L.) and rye (Secale cereale L.) [1]. The intergeneric synthetic hybrids combined the complementary traits of both parental species - the high yielding capacity of wheat and the stress tolerance of rye. Because triticale compromises the beneficial agronomic traits of wheat and the resistance to environmental stresses of rye, at the end of 20th century, the production of this cereal had significantly grown [2,3]. Triticale grain production increased twofold, from six M tons in 1995 to almost 13 M tons in 2018 worldwide. Similarly, in Poland, production increased from two $\mathrm{M}$ tons to four $\mathrm{M}$ tons over 23 years. Although the arable land for wheat $(2,417,227 \mathrm{ha})$ is twice as large as for the triticale species $(1,287,969 \mathrm{ha})$, Poland leads in the production of this crop worldwide. In Poland, triticale is cultivated twice as much as in Germany and four times more than in Belarus, France, Spain, and China [4]. Nowadays, triticale plants are used in a variety of ways, mostly as grain intended for feed production [3]. Additionally, during spring, the land cultivated for triticale is used for pasture, as fresh feed for livestock or for hay and silage. Recently triticale has also been cultivated for biofuels [3] and bioethanol [5] as well as for food production such as bread or cakes [6]. As farm animals consume triticale grain and products for human consumption are also 
made from triticale grains, it is important to maintain good quality grains, especially in the case of detrimental compounds content e.g., mycotoxins.

Recently, a decrease in triticale resistance to pathogens of the Fusarium genus has been observed. Fusarium head blight (FHB) is a destructive disease of wheat and triticale, which causes significant loss of yield and quality as well as the accumulation of hazardous mycotoxins in the grain. Numerous species of Fusarium have been associated FHB in triticale and wheat, especially Fusarium culmorum (W.G. Smith) Sacc. and F. graminearum Schwabe $[7,8]$. Suitable, rainy weather during the flowering and soft dough stages of kernel development plays a crucial role for the establishment and severity of the disease [9-13]. Fusarium develops in the infected flower, then overgrows to the next ones and afterwards spreads through the rachis along the whole head. Fusarium colonise chaff and kernels in the ear, damaging them at different levels. It reduces grain yield and grain quality by contaminating grain with mycotoxins $[14,15]$. FHB resistance consists of several mechanisms (types): resistance to initial infection (type 1), resistance to Fusarium spread within the spike (type 2), resistance to kernel infection (type 3), tolerance to accumulated toxins (type 4), resistance to accumulation of Fusarium toxins in the grain (chemical modification/synthesis inhibition = type 5) [16-18].

Resistance to FHB is a quantitative feature [19]. The presence of several quantitative trait loci (QTL) associated with FHB resistance has been reported. Loci associated with FHB resistance originate from various types of Asian spring wheats, e.g., Sumai 3, Wuhan 1, Nyubai, Wangshuibai, and Nobeokbozukomugi [20].

Breeding for improved FHB resistance is laborious task as this trait is quantitative in nature. It is greatly affected by the genetic characteristics of the host plant and fungal pathogens. Environmental conditions, mostly temperature and rainfall, from anthesis to the soft dough stage also have a substantial influence on FHB's development and make efficient selection a difficult task [9-11,14,16,21]. Breeding of cultivars resistant to FHB play a key role in disease control and the prevention of mycotoxin contamination [22-24].

Fusarium species produce secondary metabolites (mycotoxins) belonging to different chemical groups. Those most often found in cereal grains are type B trichothecenes: deoxynivalenol (DON) and nivalenol (NIV); type A trichothecenes: T-2 and HT-2 toxins; zearalenone (ZEN) and moniliformin [8]. They are extremely stable, non-metabolizable compounds with great harm to humans and animals [25]. Grain contamination with mycotoxins is found even when no reduction in yield is observed [26]. Recent research shows that triticale, like wheat, is significantly threatened by FHB and the critical accumulation of mycotoxins in grain $[27,28]$.

A large issue with modern cereal cultivation is the presence of Fusarium mycotoxins, such as NIV, DON, and ZEN in grain [29]. In 2007, the European Commission set the maximum level of deoxynivalenol in common wheat, triticale and rye grains at $1.250 \mathrm{mg} / \mathrm{kg}$ and zearalenone at $0.100 \mathrm{mg} / \mathrm{kg}$. The maximum level of DON was also established in flour at $0.750 \mathrm{mg} / \mathrm{kg}$ and in bread at $0.500 \mathrm{mg} / \mathrm{kg}$ level. The maximum ZEN content in flour was set at $0.075 \mathrm{mg} / \mathrm{kg}$ and in bread at $0.050 \mathrm{mg} / \mathrm{kg}$ (Commission Regulation (EC) no. 1126/2007) [30]. Whereas, in feed production, the lowest level of DON is required in pig feed production at $0.9 \mathrm{mg} / \mathrm{kg}$ and ZEN in piglet and sow feed production at $0.1 \mathrm{mg} / \mathrm{kg}$ (Commission Recommendation (EC) no. 2006/576) [31].

Small grain cereals differ considerably in their resistance to FHB and accumulation of mycotoxins. Research, which compared triticale and its parental forms in terms of FHB and deoxynivalenol content, revealed that triticale and rye had the lowest FHB severity and kernel damage, whereas the lowest deoxynivalenol concentration was obtained in rye followed by triticale and wheat species [29]. However, in an earlier study Langevin et al. [32] found that triticale responded similarly to wheat to the point inoculation with F. graminearum. In our study, we observed that triticale lines were more resistant to FHB and kernel damage than wheat but were similar in regard to Fusarium toxins accumulation [27]. Depending on environmental conditions and genotype, triticale could accumulate high amounts of trichothecene toxins $[15,33]$. 
The aim of this study was to compare the susceptibility of winter triticale lines to Fusarium head blight (head infection and kernel damaged) and accumulation of mycotoxins (type B trichothecenes and zearalenone) in grain. Additionally ergosterol concentration in grain was analysed. Ergosterol is main sterol compound of fungal cell membranes and can be a measure of mycelium amount in cereal kernels [34].

Experiments were established under different conditions in two locations in Poland. Plants were inoculated with Fusarium culmorum isolates. We studied different types and mechanisms of resistance: resistance to head infection, resistance to kernel damage, tolerance to accumulated toxins, and resistance to accumulation of Fusarium toxins in the grain.

\section{Materials and Methods}

\subsection{Plant Materials}

Plant material comprised 18 triticale and wheat lines of winter type (Table 1).

Table 1. Triticale and wheat lines used for the research.

\begin{tabular}{ccc}
\hline Line & Type & Pedigree \\
\hline Meloman & triticale cultivar & MAH 24050-12 $\times$ Todan \\
BOH 534-4 & triticale breeding line & BOH 9-3 $/ 4 \times$ Clever $($ wheat $)$ \\
BOH 537-2 & triticale breeding line & BOH 9-3/4 $\times$ LAD 965 $/ 98$ \\
BOH 898-1 & triticale breeding line & MAH 26699-21 $\times$ Moderato \\
BOHD 1025-2 & triticale breeding line & BOH 303 $\times$ LAD 180/00 \\
BOHD 1062-2 & triticale breeding line & DH 265 $\times$ (Salvo $\times$ Prado) \\
DANKO 6 $(2014)$ & triticale breeding line & DED 145/05 $\times$ Tulus \\
DANKO 9 $(2013)$ & triticale breeding line & DED 357 $/ 00 \times$ ADM 8 \\
DL 446/08 & triticale breeding line & (LAD 950/99 $\times$ Moderato) $\times$ Grenado \\
DL 593/07 & triticale breeding line & (DED 355 $/ 97 \times$ Grenado) $\times$ Woltario \\
DS.1238 & triticale breeding line & CHD 651 $/ 96 \times$ DED 396 $/ 95$ \\
DS.9 & triticale breeding line & Lasko $\times$ Woltario \\
LD 121/08 & triticale breeding line & DT 1282 $/ 00 \times$ Kitaro \\
MAH 33544-4 & triticale breeding line & MAH 23175-1 $/ 20 / 24 \times$ MAH 25547-2 \\
MAH 33881-1/3 a & triticale breeding line & MAH 24050-12 $\times$ Todan \\
DL 325/11/3 & wheat breeding line & (Figura $\times$ Koch) $\times$ CHD 752 $/ 01$ \\
S10 & wheat FHB resistant line & Korweta $\times$ Sumai 3 \\
S32 & wheat FHB resistant line & Turnia $\times$ Sumai 3 \\
\hline
\end{tabular}

a registered as Trefl cultivar.

Polish breeding companies (DANKO Hodowla Roślin, Choryń, Poland; Hodowla Roślin Strzelce, Choryń, Poland) developed the above triticale lines. They were selected based on low Fusarium head infection investigated in two environments [15]. Wheat breeding line was susceptible to FHB [35]. Two FHB resistant lines were developed in Plant Breeding and Acclimatization Institute NRI and carried Fhb1 resistance gene [36].

\subsection{Fungal Material for Inoculation}

The material for inoculum production consisted of three isolates of Fusarium culmorum (W.G.Sacc.). KF 846 (DON chemotype) and KF 350 (NIV chemotype) originated from the collection of the Institute of Plant Genetics Polish Academy of Sciences (Poznań, Poland). The ZFR 112 (DON chemotype, producing high amounts of ZEN in vitro) originated from the collection of Plant Breeding and Acclimatization Institute, National Research Institute (NRI) (Radzików, Poland) [37].

Isolates were incubated on autoclaved wheat grain in glass Erlenmeyer flasks $(300 \mathrm{~mL})$ for one week at $20^{\circ} \mathrm{C}$ in darkness and then exposed to near UV light (360 nm) under a $16 \mathrm{~h}$ photoperiod for 3 weeks at $15^{\circ} \mathrm{C}$. Flask were manually shaken daily to avoid the grain sticking together and to break-up the mycelial clumps. The mycelium-colonised grain with visible spore masses was air dried and stored in a refrigerator at $2-5{ }^{\circ} \mathrm{C}$. Prior to the inoculation, the grain with F. culmorum spores was soaked in distilled water for approximately 
$2 \mathrm{~h}$. Next, the suspension was filtered through a double cheesecloth layer to harvest spores and remove grains and mycelium. The conidial suspensions from three F. culmorum isolates were adjusted to 500,000 spores/mL using a haemocytometer (BRAND GmbH + Co. KG., Wertheim, Germany). Equal volumes of suspension from the three isolates were mixed.

\subsection{Field Experiment}

A three-year field experiment (2016, 2017, and 2018) was established in two locations. The first experimental field location was the Institute of Plant Genetics Polish Academy of Sciences in Cerekwica (30 km north-west from Poznań, Poland; $82 \mathrm{~m}$ above sea level; GPS coordinates $52^{\circ} 31^{\prime} 21.3^{\prime \prime} \mathrm{N}, 16^{\circ} 41^{\prime} 19.1^{\prime \prime} \mathrm{E}$ ). The second experimental field location was the Plant Breeding and Acclimatization Institute, NRI in Radzików (central Poland; $87 \mathrm{~m}$ above sea level; GPS coordinates $52^{\circ} 12^{\prime} 45.4^{\prime \prime} \mathrm{N}, 20^{\circ} 37^{\prime} 59.2^{\prime \prime} \mathrm{E}$ ). Experiments were established as randomized block designs. Triticale lines were sown in $1 \mathrm{~m}^{2}$ (Radzików) or $0.5 \mathrm{~m}^{2}$ (Cerekwica) plots in four replicates/blocks. Sowing dates were within the range from the last week of September to the first week of October. In both locations conventional tillage was applied.

In Radzików in all three years pre-crop was oilseed rape. Artificial fertilizers were applied according to standard agricultural practices in IHAR-PIB. In the autumn $3 \mathrm{dt} / \mathrm{ha}$ of Polifoska 6 (NKP(S) 6-2-30-(7)) fertilizer (Grupa Azoty Zakłady Chemiczne "Police" S.A., Police, Poland) was applied (N-18 kg/ha, P-60 kg/ha, K-90 kg/ha). In the spring, after the start of vegetation ammonium nitrate fertilizer (Grupa Azoty Zakłady Azotowe "Puławy" S.A., Puławy, Poland) was applied in an amount providing $70 \mathrm{~kg}$ N/ha. Weeds and pests were controlled with herbicides and insecticides. After sowing weeds were controlled with herbicide Maraton 375SC (BASF SE, Ludwigshafen, Germany) (isoproturon + pendimethalin) in a dose of $4 \mathrm{~L} / \mathrm{ha}$. In spring, weeds and rape self-seeders were controlled using herbicide Attribut 70SG (Bayer CropScience AG, Monheim, Germany) (propoxycarbazone-sodium) in a dose of $60 \mathrm{mg} / \mathrm{ha}$. Cereal leaf beetle and aphids were controlled with Fastac Active 050ME (BASF SE, Ludwigshafen, Germany) (alphacypermethrin) in a dose of $250 \mathrm{~mL} / \mathrm{ha}$. No fungicides were applied.

In Cerekwica pre-crop was oilseed rape $(2017,2018)$ or lacy phacelia $(2016)$. In the autumn $4 \mathrm{dt} /$ ha of Polifoska 5 (NPK(MgS) 5-15-30-(2-7)) fertilizer (Grupa Azoty Zakłady Chemiczne "Police" S.A., Police, Poland) was applied (N-20 kg/ha, P-60 kg/ha, $\mathrm{K}-120 \mathrm{~kg} / \mathrm{ha}$ ). In the spring, after the start of vegetation ammonium nitrate fertilizer (Grupa Azoty Zakłady Azotowe „Puławy” S.A., Puławy, Poland) was applied in an amount providing $70 \mathrm{~kg} \mathrm{~N} /$ ha. After sowing weeds were controlled with herbicide Legato 500SC (ADAMA Polska Sp. z o.o., Warszawa, Poland) (diflufenican) in a dose of $1.5 \mathrm{~L} / \mathrm{ha}$. No fungicides were applied.

\subsection{Inoculation Procedure}

At full anthesis (65 BBCH scale [38]), triticale and wheat lines were inoculated by spraying heads with a spore suspension [39]. Full anthesis of triticale lines in particular years was as follows 2016: Cerekwica 30-31 May, Radzików 30 May-2 June; 2017; Cerekwica 1-7 June, Radzików 8-13 June; 2018; Cerekwica 22-28 May, Radzików 29 May-3 June. For three wheat lines, this stage was on average 2-3 later than the latest triticale line. Three blocks of plots were inoculated and a fourth served as a control. Inoculation was repeated three days later.

For two days after inoculation, in Cerekwica mist irrigation was applied to maintain high moisture levels on inoculated plots [37,40]. In Radzików experimental field is located about $500 \mathrm{~m}$ from the river valley and in 2016 and 2017 average air humidity during anthesis was at a range 60-80\%. Only in 2018 (dry year in Poland) it was about at a range $50-60 \%$.

Three weeks after inoculation, disease progress was visually evaluated as the Fusarium head blight index (FHBi): 


$$
\mathrm{FHBi}=\frac{\% \text { of head infection } \times \% \text { of heads infected per plot }}{100}
$$

At harvest, 20 randomly selected heads from each plot (one control and three inoculated plots) in each location were collected. Heads were threshed with a laboratory thresher at low wind speed to prevent loss of low-weight infected kernels. Additionally after threshing the individual sample, chaff was inspected for the presence of shrivelled, low-weight FHB damaged kernels.

The percentage of Fusarium-damaged kernels (FDK) was scored visually according to the methods described earlier [41,42]. The FDK weight in relation to the weight of the whole sample was marked as FDKw, and the FDK number in relation to the total sample size was marked as FDK\#.

Reductions in the yield components caused by FHB in relation to the non-inoculated control were calculated. The components were as follow: grain yield per head, kernel number in head, and thousand kernels weight (TKW).

\subsection{Toxins and Ergosterol Analysis}

Whole grain samples were fine ground. The concentration of Fusarium toxins in triticale grain was analysed using the technique of gas chromatography. The type B trichothecenes (DON, 3-acetyldeoxynivalenol (3AcDON), 15-acetyldeoxynivalenol (15AcDON) and NIV) were detected. The methodology used for the extraction and detection of the samples with use of gas chromatography was described in detail by Góral et al. [27,43].

The content of ZEN was determined using a quantitative direct, competitive enzymelinked immunosorbent assay (ELISA) AgraQuant ${ }^{\circledR}$ Zearalenone 25-1000 (LOD 20 ppb, LOQ 25 ppb) (Romer Labs GmbH, Tulln, Austria). The detailed methodology used for the quantitative analysis of ZEN was described by Góral et al. [27].

Ergosterol (ERG) was chromatographically analysed via high-performance liquid chromatography (HPLC) on a silica column using methanol. A detailed evaluation of the method is given in a paper by Perkowski et al. [34]. Samples containing $100 \mathrm{mg}$ of ground grains were placed into $17 \mathrm{~mL}$ culture tubes, suspended in $2 \mathrm{~mL}$ of methanol, treated with $0.5 \mathrm{~mL}$ of $2 \mathrm{M}$ aqueous sodium hydroxide and tightly sealed. The culture tubes were then placed within $250 \mathrm{~mL}$ plastic bottles, tightly sealed and placed inside a microwave oven operating at $2450 \mathrm{MHz}$ and $900 \mathrm{~W}$ maximum output. Samples were irradiated $(370 \mathrm{~W})$ for $20 \mathrm{~s}$, and following approximately $5 \mathrm{~min}$, for an additional $20 \mathrm{~s}$. After $15 \mathrm{~min}$, the contents of the culture tubes were neutralized with $1 \mathrm{M}$ aqueous hydrochloric acid, $2 \mathrm{~mL} \mathrm{MeOH}$ were added and extraction with pentane $(3 \times 4 \mathrm{~mL})$ was carried out within the culture tubes. The combined pentane extracts were evaporated to dryness in a nitrogen stream. Before analysis samples were dissolved in $1 \mathrm{~mL}$ of $\mathrm{MeOH}$, they were filtered through $13 \mathrm{~mm}$ syringe filters with a $0.45 \mu \mathrm{m}$ pore diameter (Fluoropore Membrane Filters, Millipore, Corcaigh, Ireland) and $50 \mu \mathrm{L}$ were injected on HPLC column. Separation was performed on a reversed phase column Nova Pak C-18 (Waters, Milford, MA, USA), $150 \times 3.9 \mathrm{~mm}$, particle size $4 \mu \mathrm{m}$, and eluted with methanol/acetonitrile (90:10) at a flow rate of $0.6 \mathrm{~mL} / \mathrm{min}$. Ergosterol was detected with a Waters 486 Tunable Absorbance Detector (Milford, MA, USA) set at $282 \mathrm{~nm}$. The presence of ergosterol (ERG) was confirmed by a comparison of retention times and by co-injection of every tenth sample with an ergosterol standard.

\subsection{Screening of Type 1 and Type 2 FHB Resistances}

Winter triticale and wheat lines were sown in two field experiments in 2015, 2016, 2018, and 2019 in the experimental field in Radzików. Lines were sown in 1-row plots of $1 \mathrm{~m}$ length without replications. Spacing between rows was $30 \mathrm{~cm}$. Plots were covered with polyethylene tents equipped with mist irrigation system. Mist irrigation was applied after inoculations to keep high air humidity. 
In the first experiment, type 1 resistance was evaluated. At the full flowering phase (BBCH 65), the heads were sprayed with a suspension of spores of F. culmorum isolate KF 846 with a concentration of $10^{5}$ spores $/ \mathrm{mL}$. The number of infection points was assessed 7 days after inoculation. Spikelets showing necrotic spots were scored as one infection point. The methodology for assessing this resistance type was similar to that described by Kubo et al. [44] and the Patton-Ozkurt et al. methodology available on the US Wheat and Barley Scab Initiative web page [45].

In the second experiment, resistance of type 2 was evaluated. The methodology for assessing this resistance was similar to that described by Rudd et al. [46] and by G.H. Bai, available on the US Wheat and Barley Scab Initiative web page [47]. Heads were inoculated at the full flowering phase (BBCH 65) by placing a drop (approx. $50 \mu \mathrm{L}$ ) of a suspension of F. culmorum spores in the flower of the middle spikelet of labelled heads with a self-filling syringe Dosys ${ }^{\mathrm{TM}}$ classic 163/173 (Socorex ISBA SA, Ecublens, Switzerland). The suspension concentration was $50 \times 10^{3}$ spores $/ \mathrm{mL}$, which gave about 2500 spores per suspension drop. The same isolate KF 846 was used. Ten heads per line were inoculated. The severity of FHB was assessed by determining the number of infected spikelet per head 21 days after inoculation. The infection symptoms include necrosis, whitening of the spikelets, in some cases Fusarium sporulation in the form of a pink-orange sporodochia.

\subsection{Statistical Analysis}

Statistical analysis was made using Microsoft ${ }^{\circledR}$ Excel 2016/XLSTAT@ (Version 2020.4.1.1027, Addinsoft, Paris, France) statistical software.

FHB and FDK ratings, reduction of yield components and concentration of ERG and toxins data were analysed by means of analysis of variance (ANOVA) using the XLSTAT procedure: Modelling data-ANOVA. Year effect was considered random and location and line were considered fixed. Normality of data distribution was tested with the ShapiroWilk test (XLSTAT procedure: Normality test). All variables were not normally distributed; hence, they were transformed with the square root (FHBi, FDKw, FDK\#, yield reduction, kernel\# reduction, TKW reduction) or log10 (ERG, DON, 3ADON, 15AcDON, NIV, trichothecenes (TCT B), ZEN) transformations.

The relationships between resistance type 1 and type 2, FHBi, FDK, reduction in the yield components and the ERG and mycotoxins concentrations were analysed using Pearson's correlation tests (XLSTAT procedure: Correlation tests). Prior to analysis, variables (means for 18 lines) that were not normally distributed were square root (FHBi, FDKw, FDK\#, yield reduction, kernel\# reduction, TKW reduction) or log10 transformed (type 1, type 2 , type $1+2$, ERG).

The data on FHB resistance (FHBi, FDKw, yield reduction, TKW reduction, ERG, DON, NIV, ZEN) measured with different units were analysed together using multivariate statistical analysis. Principal component analysis (XLSTAT procedure: Principal Component Analysis PCA) was used to show how triticale (and wheat) lines are distributed with respect to the variation described by the first two principal components and how FHB resistance variables influenced the two components. PCA results also show relations among variables measured by the angle among variable vectors.

\section{Results}

No FHB symptoms were observed on control plots. The average severity of FHB on inoculated plots was $\mathrm{FHBi}=10.7 \%$. It was similar in both locations and amounted to $11.3 \%$ in Radzików and $9.7 \%$ in Cerekwica (Figure 1). The range of reactions was from $0 \%$ to $64.0 \%$ in Radzików and from $2.7 \%$ to $40.0 \%$ in Cerekwica. The proportion of Fusarium-damaged kernels was higher in Cerekwica (FDKw $=34.9 \%$; FDK\# $=27.9 \%$ ) than in Radzików (FDKw $=12.7 \%$; FDK\# $=11.4 \%$ ). The range of reaction was from $0.2 \%$ to $47.3 \%$ in Radzików and from $0.3 \%$ to $84.5 \%$ in Cerekwica for FDKw and from $0.6 \%$ to $51.4 \%$ in Radzików, and from $0.2 \%$ to $88.6 \%$ in Cerekwica for FDK\#. 


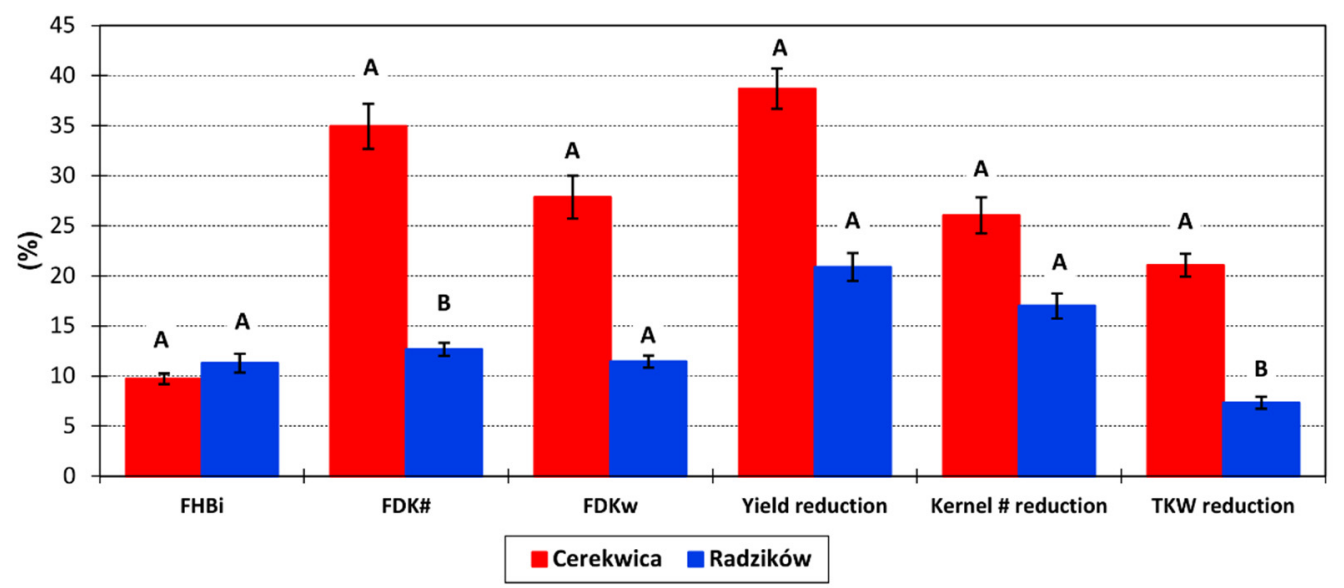

Figure 1. Average Fusarium head blight index (FHBi), Fusarium-damaged kernels proportion (FDK\#number, FDKw-weight) and reductions in the yield components (grain yield per head, kernel number in head, and 1000 kernels weight (TKW)) in two experimental locations. The data are means \pm SEM $(n=162)$. Means marked with the same letter are not significantly different at $p<0.05$ according to Fisher's LSD test performed on transformed variables.

Over three experimental years, the FHB index amounted to $14.4 \%$ in $2016,13.6 \%$ in 2017 , and $4.0 \%$ in 2018. As regards the FDK proportion, it was $21.2 \%$ and $26.2 \%$ in 2016 , $22.8 \%$ and $25.2 \%$ in 2017, and $10.0 \%$ and $13.4 \%$ in 2018 for FDKw and FDK\#, respectively.

Reductions in the three studied yield components were, on average, grain yield $28.3 \%$, kernel number $20.8 \%$, and TKW $13.0 \%$. In the experiment in the Cerekwica, the reductions were higher than in Radzików (Figure 1). Over the three experimental years, the reductions in yield, kernel number and TKW were as follows: $26.3 \%, 16.2 \%$, and $14.9 \%$ in $2016 ; 27.8 \%$, $21.8 \%$, and $13.0 \%$ in 2017; and 30.7\%, 24.3\%, and $11.0 \%$ in 2018 .

Concentration of ERG in grain was, on average, $8.3 \mathrm{mg} / \mathrm{kg}$. It was similar for both locations (Figure 2). The concentration range was $1.5-38.7 \mathrm{mg} / \mathrm{kg}$ in Cerekwica and 0.6-35.2 mg/kg in Radzików. In 2016, the average ERG content in grain was $5.6 \mathrm{mg} / \mathrm{kg}$, in $20178.8 \mathrm{mg} / \mathrm{kg}$ and in $201811.0 \mathrm{mg} / \mathrm{kg}$.

The amount of DON in grain was, on average, $7.258 \mathrm{mg} / \mathrm{kg}$ at a range $0.028-50.330 \mathrm{mg} / \mathrm{kg}$ and the amount of NIV in grain was $5.267 \mathrm{mg} / \mathrm{kg}$ in the range $0-44.628 \mathrm{mg} / \mathrm{kg}$. In Radzików, the concentration of DON was twice as high as in Cerekwica (Figure 2). On the contrary, the concentration of NIV in Radzików was low $(0.855 \mathrm{mg} / \mathrm{kg})$ and 10 times lower than in Cerekwica $(9.679 \mathrm{mg} / \mathrm{kg})$. Over the three experimental years, the amounts of DON and NIV were as follows: $2016-5.991$ and $4.402 \mathrm{mg} / \mathrm{kg}$; 2017-13.248 and $7.974 \mathrm{mg} / \mathrm{kg}$; and $2018-2.536$ and $3.426 \mathrm{mg} / \mathrm{kg}$.

Acetylated derivatives of DON (e.g., $3 \mathrm{AcDON}$ and $15 \mathrm{AcDON}$ ) were detected in low amounts. On average, it was $0.228 \mathrm{mg} / \mathrm{kg}$ of $3 \mathrm{AcDON}(0-1.352 \mathrm{mg} / \mathrm{kg})$ and $0.035 \mathrm{mg} / \mathrm{kg}$ of $15 A c D O N(0-0.445 \mathrm{mg} / \mathrm{kg})$. In Cerekwica, the concentration of 3AcDON and $15 A c D O N$ was 0.284 and $0.001 \mathrm{mg} / \mathrm{kg}$, respectively, and in Radzików 0.172 and $0.068 \mathrm{mg} / \mathrm{kg}$. Over the three experimental years, the amounts of $3 \mathrm{AcDON}$ and $15 \mathrm{AcDON}$ were as follows: 2016 0.236 and $0.019 \mathrm{mg} / \mathrm{kg}$; 2017—0.444 and $0.078 \mathrm{mg} / \mathrm{kg}$; and 2018—0.004 and $0.007 \mathrm{mg} / \mathrm{kg}$. 


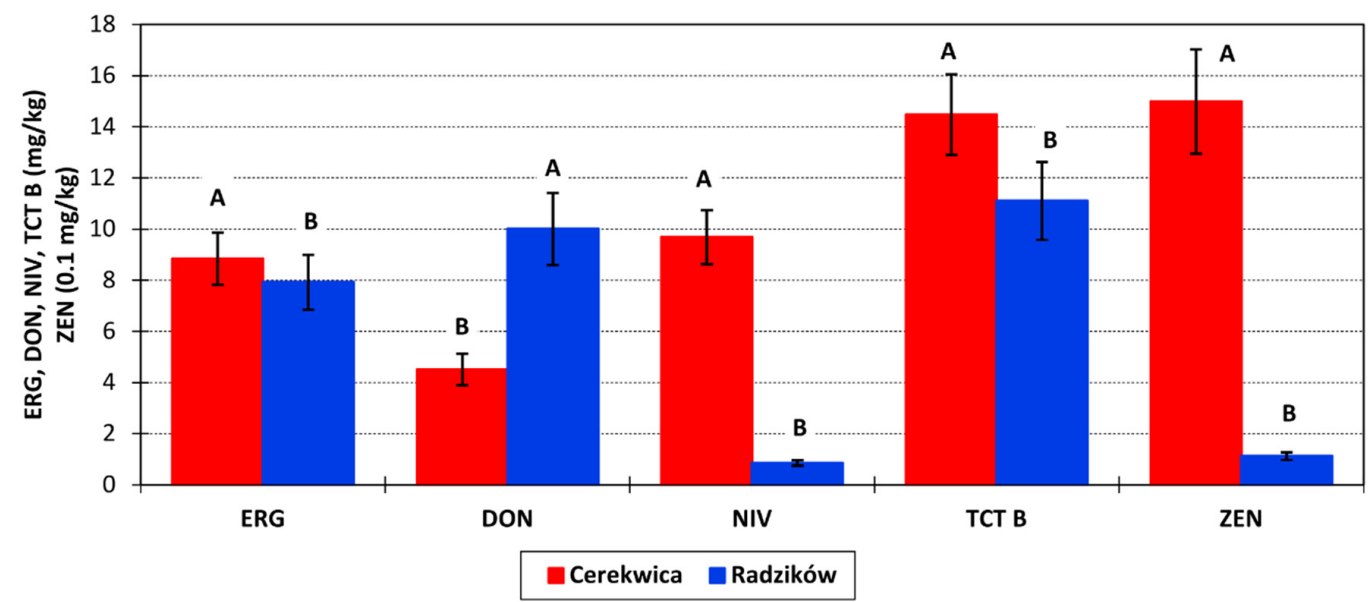

Figure 2. Average concentration of ergosterol (ERG), deoxynivalenol (DON), nivalenol (NIV), type B trichothecenes (TCT B), and zearalenone (ZEN) in grain of 15 triticale and 3 wheat lines in two experimental locations. Neither 3-acetyldeoxynivalenol (3AcDON) nor 15-acetyldeoxynivalenol $(15 \mathrm{AcDON})$ are shown. The data are means $\pm \operatorname{SEM}(n=54)$. Means marked with the same letter are not significantly different at $p<0.05$ according to Fisher's LSD test performed on transformed variables.

The total amount of analyzed type B trichothecenes was $12.788 \mathrm{mg} / \mathrm{kg}$ at a range of $0.100-65.565 \mathrm{mg} / \mathrm{kg}$. In Cerekwica, the amount of TCT B was $14.476 \mathrm{mg} / \mathrm{kg}$ at a range $1.453-65.565 \mathrm{mg} / \mathrm{kg}$, and in Radzików $11.101 \mathrm{mg} / \mathrm{kg}$ at a range $0.100-53.595 \mathrm{mg} / \mathrm{kg}$. Over three years, the average amount of TCT B was as follows: $2016-10.648 \mathrm{mg} / \mathrm{kg}$, $2017-21.744 \mathrm{mg} / \mathrm{kg}$, and $2018-5.973 \mathrm{mg} / \mathrm{kg}$.

Zearalenone was detected in grain at an average amount of $0.805 \mathrm{mg} / \mathrm{kg}$. The amount ranged from 0 to $5.055 \mathrm{mg} / \mathrm{kg}$. ZEN was present mainly in samples from Cerekwica at amount of $1.500 \mathrm{mg} / \mathrm{kg}$. In samples from Radzików, the concentration was 10 times lower and amounted to $0.112 \mathrm{mg} / \mathrm{kg}$. The highest concentration of ZEN was detected in 2017 at $1.446 \mathrm{mg} / \mathrm{kg}$, followed by 2016 at $0.900 \mathrm{mg} / \mathrm{kg}$. In 2018, it was very low at $0.071 \mathrm{mg} / \mathrm{kg}$.

Winter wheat lines showed the highest (DL 325/11/3) and the lowest (lines carrying Fhb1 resistance gene) values of FHB index (Table 2). Among triticale lines, the lowest FHBi was observed for six lines: DANKO 9 (2013), LD 121/08, BOHD 1025-2, BOH 534-4, MAH 33881-1/3, and DS.9. The most infected heads had two lines DANKO 6 (2014), DL 446/08, and cultivar Meloman. The lowest FDK proportions (weight and number) were observed for two low FHB infected wheat lines. FHB-susceptible wheat lines showed only medium FDK values. Low FDK's were found only for two low FHB-infected triticale: DS.9 and BOHD 1025-2. The highest kernel damage was observed in line DANKO 9 (2013) that showed only weak FHB symptoms. FDK was also high in three lines, which showed the highest FHB index among triticale lines DANKO 6 (2014), DL 446/08, and BOHD 1062-2.

Reduction of grain yield per head was the highest in triticale line DANKO 6 (2014) as well as wheat line DL 325/11/3. These lines showed high levels of head infection and kernel damage. This was also noted in lines DANKO 9 (2013) and LD 121/08. The second line showed low head and kernel infection. Line DANKO 9 (2013) had the lowest average grain yield per head in control plots while line DANKO 6 (2014) the highest. Line LD $121 / 08$ had medium yield. Low reduction of grain yield was found in resistant wheat lines and low-infected triticale BOH 534-4 and DS.9 as well as in medium-infected line $\mathrm{BOH}$ 537-2. Lines DS.9 and BOH 537-2 had average grain yield per head in control plots below mean value while line BOH 534-4 above mean value. Reduction of 1000 kernel weight was the highest in the susceptible wheat line DL $325 / 11 / 3$ and the lowest in resistant wheat lines and resistant triticale line DS.9. 
Table 2. Fusarium head blight index (\%), Fusarium-damaged kernels (weight. number) (\%) and reduction of yield, kernel number, and TKW (\%) for 15 winter triticale and three winter wheat lines.

\begin{tabular}{|c|c|c|c|c|c|c|}
\hline Line & FHBi & FDKw & FDK\# & $\begin{array}{c}\text { Yield } \\
\text { Reduction }\end{array}$ & $\begin{array}{l}\text { Kernel Number } \\
\text { Reduction }\end{array}$ & $\begin{array}{c}\text { TKW } \\
\text { Reduction }\end{array}$ \\
\hline $\operatorname{DL} 325 / 11 / 3^{a}$ & $32.6 \mathrm{a}$ & $25.7 \mathrm{abcd}$ & $22.2 \mathrm{abcd}$ & $41.9 \mathrm{ab}$ & 27.1 & $22.7 \mathrm{a}$ \\
\hline Meloman & $14.0 \mathrm{bcd}$ & 22.8 bcde & 18.5 bcde & 33.3 abcde & 25.5 & 10.8 bcde \\
\hline DANKO 6 (2014) & $13.9 \mathrm{~b}$ & $31.0 \mathrm{ab}$ & $25.2 \mathrm{ab}$ & $44.4 \mathrm{a}$ & 36.4 & $18.7 \mathrm{abc}$ \\
\hline DL $446 / 08$ & $13.5 \mathrm{bc}$ & $30.8 \mathrm{ab}$ & $26.5 \mathrm{ab}$ & 29.7 cde & 23.3 & $13.8 \mathrm{bcd}$ \\
\hline BOHD 1062-2 & 11.6 bcde & $28.0 \mathrm{abc}$ & $24.8 \mathrm{abc}$ & 27.0 cde & 20.8 & $14.7 \mathrm{bcd}$ \\
\hline ВOH 898-1 & 10.7 bcdef & 23.1 abcde & 18.1 abcde & 24.3 cde & 17.4 & 10.5 bcde \\
\hline ВOH 537-2 & 10.2 bcdef & 20.8 abcde & 18.1 bcde & 23.5 ef & 16.1 & 11.4 bcde \\
\hline DL 593/07 & 9.5 cdef & 23.6 abcde & 19.6 abcde & 29.0 bcde & 22.0 & 11.8 cdef \\
\hline MAH 33544-4 & 9.4 bcdef & 18.0 cde & 13.9 cde & 28.0 abcde & 19.1 & $14.3 \mathrm{abc}$ \\
\hline DS.1238 & 9.4 bcdef & 24.7 abcde & 21.2 abcde & 26.9 cde & 19.8 & $12.3 \mathrm{bcd}$ \\
\hline DANKO 9 (2013) & 9.1 ef & $33.6 \mathrm{a}$ & $28.6 \mathrm{a}$ & $35.6 \mathrm{abc}$ & 22.6 & $16.3 \mathrm{abc}$ \\
\hline LD 121/08 & 9.0 ef & 18.6 bcde & 15.6 cde & $35.8 \mathrm{abcd}$ & 27.9 & $13.8 \mathrm{bcd}$ \\
\hline BOHD 1025-2 & $8.6 \mathrm{def}$ & $14.4 \mathrm{e}$ & $11.8 \mathrm{e}$ & 26.0 cde & 17.5 & $13.2 \mathrm{bcd}$ \\
\hline BOH 534-4 & 8.4 ef & 21.3 abcde & 17.6 bcde & 23.9 ef & 15.8 & $12.0 \mathrm{bcd}$ \\
\hline МАН 33881-1/3 & $7.1 \mathrm{f}$ & 22.7 abcde & 19.1 abcde & 25.6 cde & 15.1 & $16.7 \mathrm{ab}$ \\
\hline DS. 9 & $7.1 \mathrm{f}$ & $16.7 \mathrm{de}$ & $13.0 \mathrm{de}$ & 23.4 def & 21.0 & 8.0 ef \\
\hline $\mathrm{S} 10^{\mathrm{a}}$ & $4.0 \mathrm{~g}$ & $4.0 \mathrm{f}$ & $3.4 \mathrm{f}$ & $14.4 \mathrm{~g}$ & 13.1 & $4.5 \mathrm{f}$ \\
\hline $\mathrm{S} 32^{\mathrm{a}}$ & $3.9 \mathrm{~g}$ & $8.7 \mathrm{f}$ & $7.1 \mathrm{f}$ & $16.0 \mathrm{fg}$ & 13.2 & $7.6 \mathrm{def}$ \\
\hline Means & 10.7 & 18.1 & 21.6 & 28.3 & 20.8 & 12.9 \\
\hline
\end{tabular}

${ }^{a}$ wheat; those marked with the same letter are not significantly different at $p<0.05$ according to Fisher's least significant difference (LSD) test performed on transformed variables; means ranked by FHBi values.

Ergosterol concentration was the highest in grain of susceptible wheat line DL 325/11/3 (Table 3). It was twice as high as in two triticale lines that had the highest concentrations of this metabolite (DANKO 6 (2014) and BOHD 1062-2). These lines had also high kernel damage. Line DANKO 9 (2013) exhibiting highest kernel damage had medium concentration of ERG in grain. The lowest ERG content was found in grain of five triticale lines DS. 9, BOH 898-1, BOHD 1025-2, BOH 534-4, and BOH 537-2. FHB-resistant wheat lines had medium concentration of ERG in grain.

Deoxynivalenol accumulated the highest amount in grain of the triticale line DANKO 6 (2014) and in the wheat line DL 325/11/3. Four triticale lines, BOHD 1062-2, DL 446/08, DANKO 9 (2013) and DS.1238, also had high amounts of DON in grain. The lowest concentration of DON was detected in the grain of resistant wheat lines and two triticale lines BOH 534-4 and BOHD 1025-2. Nivalenol was present mainly in the grain of four triticale lines: DANKO 6 (2014), BOHD 1062-2, DL 446/08, DANKO 9 (2013), and MAH 33881-1/3. The lowest concentration of NIV was detected in the grain of resistant wheat lines and two triticale lines DS.9 and BOHD 1025-2. 3AcDON was detected mainly in susceptible wheat line and triticale line DANKO 6 (2014), that accumulated high amount of trichothecene toxins. Of the total amount of the four trichothecenes, the highest was in the grain of three triticale lines DANKO 6 (2014), BOHD 1062-2, and DL 446/08, and the lowest was in the grain of resistant wheat lines. The wheat line "DL 325/11/3" had a medium amount of type B trichothecenes in grain. Four triticale lines, BOH 898-1, DS. 9, BOH 534-", and BOHD 1025-2, accumulated the lowest amounts of type B trichothecenes.

Differences in ZEN concentrations among triticale lines had low significance. The lowest amount of ZEN was found in the grain of the DS.9 line. Considerably lower amounts of ZEN accumulated only in the grain of resistant wheat lines. 
Table 3. Concentration of ergosterol (mg/kg), type B trichothecenes (DON, 3AcDON, 15AcDON, NIV, and TCT B) (mg/kg) and zearalenone $(\mathrm{mg} / \mathrm{kg})$ in grain of 15 winter triticale and three winter wheat lines.

\begin{tabular}{cccccccc}
\hline Line & ERG & DON & 3Ac DON & 15Ac DON & NIV & TCT B b & ZEN \\
\hline DANKO 6 (2014) & $13.0 \mathrm{~b}$ & $14.327 \mathrm{a}$ & $0.426 \mathrm{ab}$ & 0.081 & $7.653 \mathrm{ab}$ & $22.487 \mathrm{a}$ & $0.966 \mathrm{ab}$ \\
BOHD 1062-2 & $12.1 \mathrm{bc}$ & $10.207 \mathrm{ab}$ & $0.327 \mathrm{abcd}$ & 0.012 & $10.966 \mathrm{a}$ & $21.511 \mathrm{ab}$ & $1.443 \mathrm{abc}$ \\
DL 446/08 & $9.4 \mathrm{bcde}$ & $10.882 \mathrm{abcd}$ & $0.374 \mathrm{abc}$ & 0.050 & $10.197 \mathrm{a}$ & $21.503 \mathrm{ab}$ & $0.956 \mathrm{ab}$ \\
DANKO 9 (2013) & $8.6 \mathrm{bcde}$ & $10.944 \mathrm{abc}$ & $0.321 \mathrm{abcd}$ & 0.043 & $7.838 \mathrm{a}$ & $19.146 \mathrm{abc}$ & $1.169 \mathrm{a}$ \\
MAH 33881-1/3 & $6.4 \mathrm{~b}-\mathrm{g}$ & $9.380 \mathrm{abcd}$ & $0.251 \mathrm{abcde}$ & 0.046 & $7.974 \mathrm{a}$ & $17.652 \mathrm{abc}$ & $0.791 \mathrm{abcd}$ \\
DL 325/11/3 a & $28.3 \mathrm{a}$ & $11.887 \mathrm{ab}$ & $0.461 \mathrm{a}$ & 0.021 & $4.930 \mathrm{abcd}$ & $17.298 \mathrm{abc}$ & $0.833 \mathrm{ab}$ \\
DS.1238 & $7.5 \mathrm{~b}-\mathrm{g}$ & $10.549 \mathrm{abcde}$ & $0.335 \mathrm{abcde}$ & 0.072 & $4.981 \mathrm{abcd}$ & $15.937 \mathrm{abcd}$ & $1.238 \mathrm{a}$ \\
Meloman & $9.5 \mathrm{bcd}$ & $9.089 \mathrm{abcde}$ & $0.214 \mathrm{~b}-\mathrm{g}$ & 0.064 & $5.733 \mathrm{abc}$ & $15.101 \mathrm{abcd}$ & $0.999 \mathrm{abcd}$ \\
DL 593/07 & $6.2 \mathrm{~b}-\mathrm{g}$ & $7.278 \mathrm{bcdef}$ & $0.224 \mathrm{bcdef}$ & 0.070 & $5.856 \mathrm{abcd}$ & $13.429 \mathrm{bcde}$ & $0.921 \mathrm{abc}$ \\
MAH 33544-4 & $5.8 \mathrm{~b}-\mathrm{g}$ & $5.204 \mathrm{cdef}$ & $0.161 \mathrm{c}-\mathrm{g}$ & 0.015 & $6.301 \mathrm{abc}$ & $11.681 \mathrm{cde}$ & $0.635 \mathrm{abc}$ \\
BOH 537-2 & $5.4 \mathrm{defg}$ & $6.447 \mathrm{bcdef}$ & $0.139 \mathrm{defg}$ & 0.031 & $3.657 \mathrm{bcde}$ & $10.273 \mathrm{def}$ & $0.757 \mathrm{ab}$ \\
LD 121/08 & $5.7 \mathrm{~b}-\mathrm{g}$ & $4.338 \mathrm{f}$ & $0.165 \mathrm{c}-\mathrm{g}$ & 0.026 & $4.611 \mathrm{bcde}$ & $9.139 \mathrm{ef}$ & $0.763 \mathrm{bcd}$ \\
BOH 898-1 & $3.7 \mathrm{fg}$ & $5.387 \mathrm{ef}$ & $0.182 \mathrm{c}-\mathrm{g}$ & 0.026 & $2.958 \mathrm{def}$ & $8.553 \mathrm{ef}$ & $0.720 \mathrm{abc}$ \\
DS.9 & $4.9 \mathrm{efg}$ & $5.111 \mathrm{def}$ & $0.137 \mathrm{defg}$ & 0.019 & $2.888 \mathrm{efg}$ & $8.156 \mathrm{ef}$ & $0.529 \mathrm{bcd}$ \\
BOH 534-4 & $4.9 \mathrm{cdefg}$ & $3.977 \mathrm{f}$ & $0.173 \mathrm{c}-\mathrm{g}$ & 0.019 & $3.440 \mathrm{cde}$ & $7.609 \mathrm{ef}$ & $0.846 \mathrm{abc}$ \\
BOHD 1025-2 & $4.2 \mathrm{~g}$ & $3.086 \mathrm{fg}$ & $0.116 \mathrm{efg}$ & 0.008 & $2.492 \mathrm{efg}$ & $5.701 \mathrm{f}$ & $0.775 \mathrm{abcd}$ \\
S 32 $\mathrm{a}$ & $7.5 \mathrm{~b}-\mathrm{g}$ & $1.161 \mathrm{~h}$ & $0.045 \mathrm{~g}$ & 0 & $1.362 \mathrm{fg}$ & $2.567 \mathrm{~g}$ & $0.061 \mathrm{~d}$ \\
S 10 ${ }^{\mathrm{a}}$ & $7.7 \mathrm{~b}-\mathrm{f}$ & $1.398 \mathrm{gh}$ & $0.053 \mathrm{fg}$ & 0.021 & $0.976 \mathrm{~g}$ & $2.448 \mathrm{~g}$ & $0.092 \mathrm{~cd}$ \\
\hline Means & 8.4 & 7.258 & 0.228 & 0.035 & 5.267 & 12.788 & 0.805 \\
\hline
\end{tabular}

${ }^{\mathrm{a}}$ wheat; $^{\mathrm{b}}$ sum of DON, $3 \mathrm{AcDON}, 15 \mathrm{AcDON}$, and NIV; means marked with the same letter are not significantly different at $p<0.05$ according to Fisher's LSD test performed on transformed variables; means ranked by TCT B concentration.

The Fusarium head blight index correlated significantly with other variables except 15 AcDON and NIV (Table 4$)$. Coefficients had high values $(>0.600)$ but were low for the sum of type B trichothecenes and ZEN concentrations. Fusarium-damaged kernel proportions (i.e., weight and number) correlated highly significantly with reductions in yield components and concentration of mycotoxins. The highest values had coefficients of correlations with TCT B and ZEN. The FDKs did not correlate with the ERG amount in grain. This resulted from higher than expected FDK value concentrations of ERG in grain of the wheat lines. For sole triticale lines, FDKs correlated significantly with ERG ( 0.768 and 0.759). Reductions in the yield components correlated significantly with concentrations of ERG and mycotoxins. The highest were coefficients of correlation with DON and 3AcDON, the lowest with ERG and NIV.

Ergosterol concentration in grain correlated significantly with DON and 3AcDON and did not correlate with the amounts NIV and ZEN. Trichothecene toxins correlated significantly with each other and with ZEN. The highest values had coefficients of correlation DON versus $3 A c D O N$ and DON versus NIV.

Analysis of variance of the FHB index showed a very high effect of the triticale/wheat line and no effect of year (random) and location (Table 5). No interaction year $\times$ line was observed. Highly significant interactions for year $\times$ location and location $\times$ line were found. Similarly, for FDKw and FDK\#, the effect of line was highly significant as well year $\times$ location interaction. Interactions for location $\times$ line were not significant for FDK. For reductions in yield component, the effects of line were significant for grain yield and TKW but not for kernel number. Year $\times$ location interactions were significant for all components (Table 6). 
Table 4. Coefficients of correlation between Fusarium head blight index, Fusarium-damaged kernels proportion (weight, number), reductions in yield components and concentration of ergosterol and mycotoxins in grain of 15 winter triticale and three winter wheat lines.

\begin{tabular}{|c|c|c|c|c|c|c|c|c|c|c|c|c|}
\hline Variables & FHBi & FDKw & FDK \# & $\begin{array}{l}\text { Yield } \\
\text { Red. }\end{array}$ & $\begin{array}{c}\text { Kernel\# } \\
\text { Red. }\end{array}$ & $\begin{array}{l}\text { TKW } \\
\text { Red. }\end{array}$ & ERG & DON & $\begin{array}{c}3 A c \\
\text { DON }\end{array}$ & $\begin{array}{l}\text { 15Ac } \\
\text { DON }\end{array}$ & NIV & ТСТ В \\
\hline FDKw & $0.611^{* *}$ & & & & & & & & & & & \\
\hline FDK\# & $0.606^{* *}$ & 0.996 & & & & & & & & & & \\
\hline Yield red. & 0.763 & 0.753 & 0.766 & & & & & & & & & \\
\hline $\begin{array}{l}\text { Kernel\# } \\
\text { red. }\end{array}$ & $0.645^{* *}$ & $0.609 * *$ & $0.628^{* *}$ & 0.915 & & & & & & & & \\
\hline TKW red. & 0.740 & 0.774 & 0.770 & 0.844 & $0.612 * *$ & & & & & & & \\
\hline ERG & 0.698 & $0.362^{\mathrm{ns}}$ & $0.326^{\text {ns }}$ & $0.532 *$ & 0.526 * & $0.526^{*}$ & & & & & & \\
\hline DON & $0.673^{* *}$ & 0.865 & 0.855 & 0.773 & 0.699 & 0.750 & $0.656^{* *}$ & & & & & \\
\hline $3 \mathrm{AcDON}$ & 0.769 & 0.837 & 0.822 & 0.787 & 0.700 & 0.806 & 0.730 & 0.949 & & & & \\
\hline $15 \mathrm{AcDON}$ & $0.227^{\mathrm{ns}}$ & $0.531 *$ & 0.540 * & $0.501 *$ & 0.543 * & $0.269^{\mathrm{ns}}$ & $0.216^{\mathrm{ns}}$ & $0.674^{* *}$ & 0.540 * & & & \\
\hline NIV & $0.376^{\mathrm{ns}}$ & 0.789 & 0.773 & $0.549^{*}$ & 0.479 * & $0.632 * *$ & $0.432^{\text {ns }}$ & 0.773 & 0.724 & $0.413^{\mathrm{ns}}$ & & \\
\hline TCT B & 0.584 * & 0.884 & 0.870 & 0.721 & $0.644^{* *}$ & 0.744 & $0.598^{* *}$ & 0.960 & 0.908 & $0.599^{* *}$ & 0.920 & \\
\hline ZEN & 0.484 * & 0.879 & 0.864 & $0.627^{* *}$ & $0.506^{*}$ & $0.635^{* *}$ & $0.276^{\mathrm{ns}}$ & 0.753 & 0.717 & 0.483 * & 0.750 & 0.797 \\
\hline
\end{tabular}

Coefficients significant at $p<0.001$, except when marked with $* * * *$, ${ }^{*}$ —significant at $p<0.05,0.01$ or non-significant, respectively.

Table 5. Analysis of variance of Fusarium head blight index (FBI) and Fusarium-damaged kernels percentage (weight, number).

\begin{tabular}{|c|c|c|c|c|c|c|c|}
\hline \multirow[b]{2}{*}{ Source } & \multirow[b]{2}{*}{ DF } & \multicolumn{2}{|c|}{ FHBi } & \multicolumn{2}{|c|}{ FDKw } & \multicolumn{2}{|c|}{ FDK\# } \\
\hline & & $\begin{array}{c}\text { Mean } \\
\text { Squares }\end{array}$ & $\mathbf{F}$ & $\begin{array}{c}\text { Mean } \\
\text { Squares }\end{array}$ & $\mathbf{F}$ & $\begin{array}{c}\text { Mean } \\
\text { Squares }\end{array}$ & $\mathbf{F}$ \\
\hline Year & 2 & 91.803 & 6.178 & 73.178 & 1.001 & 54.475 & 1.155 \\
\hline Location & 1 & 1.830 & 0.122 & 170.582 & 2.306 & 298.949 & $6.259 *$ \\
\hline Line & 17 & 7.071 & $16.109 * * *$ & 12.880 & $6.355^{* * *}$ & 15.348 & $7.110^{* * *}$ \\
\hline Year $\times$ Location & 2 & 15.026 & $24.799 * * *$ & 73.981 & $25.486^{* * *}$ & 47.765 & $17.377^{* * *}$ \\
\hline Year $\times$ Line & 34 & 0.439 & 0.724 & 2.027 & 0.698 & 2.159 & 0.785 \\
\hline Location $\times$ Line & 17 & 4.087 & $6.744^{* * *}$ & 3.482 & 1.200 & 4.565 & 1.661 \\
\hline Year $\times$ Location $\times$ Line & 34 & 0.606 & 1.449 & 2.903 & $6.762^{* * *}$ & 2.749 & $5.223 * * *$ \\
\hline Error & 162 & 0.418 & & 0.429 & & 0.526 & \\
\hline
\end{tabular}

$* * *, *$ significant at $p<0.001$ and 0.05 , respectively.

Table 6. Analysis of variance of reductions in yield per head, kernel number in head, and 1000 kernel weight.

\begin{tabular}{|c|c|c|c|c|c|c|c|}
\hline \multirow[b]{2}{*}{ Source } & \multirow[b]{2}{*}{ DF } & \multicolumn{2}{|c|}{ Yield } & \multicolumn{2}{|c|}{ Kernel Number } & \multicolumn{2}{|c|}{ TKW } \\
\hline & & $\begin{array}{c}\text { Mean } \\
\text { Squares }\end{array}$ & $\mathbf{F}$ & $\begin{array}{c}\text { Mean } \\
\text { Squares }\end{array}$ & $\mathbf{F}$ & $\begin{array}{c}\text { Mean } \\
\text { Squares }\end{array}$ & $\mathbf{F}$ \\
\hline Year & 2 & 7.919 & 0.038 & 25.939 & 0.175 & 9.829 & 0.179 \\
\hline Location & 1 & 263.319 & 1.285 & 94.387 & 0.641 & 317.916 & $5.845 *$ \\
\hline Line & 17 & 16.187 & $3.579^{* * *}$ & 11.723 & 1.856 & 8.286 & $2.545^{* *}$ \\
\hline Year $\times$ Location & 2 & 204.966 & $56.587^{* * *}$ & 147.266 & $28.703^{* * *}$ & 54.392 & $20.617^{* * *}$ \\
\hline Year $\times$ Line & 34 & 4.522 & 1.249 & 6.316 & 1.231 & 3.256 & 1.234 \\
\hline Location $\times$ Line & 17 & 6.666 & 1.840 & 10.997 & $2.143 *$ & 3.795 & 1.438 \\
\hline Year $\times$ Location $\times$ Line & 34 & 3.622 & $2.924 * * *$ & 5.131 & $3.929 * * *$ & 2.638 & $5.634^{* * *}$ \\
\hline Error & 162 & 1.239 & & 1.306 & & 0.468 & \\
\hline
\end{tabular}

$* * * * * * *$ significant at $p<0.001,0.01$ and 0.05 , respectively.

We found highly significant effects of year on concentration of all analyzed toxins (Tables 7 and 8). Location had a highly significant effect on concentration of trichothecenes and ZEN but only weak one on ERG concentration. 
Table 7. Analysis of variance of concentration of ergosterol, DON, 3ACDON, and 15AcDON in grain.

\begin{tabular}{|c|c|c|c|c|c|c|c|c|c|}
\hline \multirow{2}{*}{ Source } & \multirow{2}{*}{ DF } & \multicolumn{2}{|c|}{ ERG } & \multicolumn{2}{|c|}{ DON } & \multicolumn{2}{|c|}{$3 \mathrm{AcDON}$} & \multicolumn{2}{|c|}{ 15AcDON } \\
\hline & & MS & $F$ & MS & $F$ & MS & $F$ & MS & $F$ \\
\hline Year & 2 & 1.154 & $25.786^{* * *}$ & 3.634 & $87.057^{* * *}$ & 0.200 & $70.513^{* * *}$ & 0.008 & $10.253^{* * *}$ \\
\hline Location & 1 & 0.193 & $4.311 *$ & 2.087 & $49.989^{* * *}$ & 0.031 & $11.008^{* * *}$ & 0.018 & $24.035^{* * *}$ \\
\hline Line & 17 & 0.187 & $4.190^{* * *}$ & 0.259 & $6.203^{* * *}$ & 0.008 & $2.876^{* * *}$ & 0.000 & 0.635 \\
\hline Error & 87 & 0.045 & & 0.042 & & 0.003 & & 0.001 & \\
\hline
\end{tabular}

$* * *, *$ significant at $p<0.001$ and 0.05 , respectively

Location mean squares for $15 \mathrm{AcDON}, \mathrm{NIV}$, and ZEN were higher than year mean squares. These toxins were mainly detected in samples from Radzików (15AcDON) or Cerekwica (NIV, ZEN) (Figure 2). The effect of the triticale line was highly significant for ERG and trichothecenes (except 15AcDON) and low significant for ZEN.

Table 8. Analysis of variance of concentration of nivalenol, trichothecenes B (sum of DON, 3AcDON, 15AcDON, and NIV) and zearalenone in grain.

\begin{tabular}{cccccccc}
\hline \multirow{2}{*}{ Source } & DF & \multicolumn{2}{c}{ NIV } & \multicolumn{2}{c}{ TCT B } & \multicolumn{2}{c}{ ZEN } \\
\cline { 3 - 8 } & & MS & F & MS & F & MS & F \\
\hline Year & 2 & 0.825 & $31.975^{* * *}$ & 2.526 & $74.300^{* * *}$ & 13.499 & $18.648^{* * *}$ \\
Location & 1 & 13.156 & $509.917^{* * *}$ & 0.719 & $21.139^{* * *}$ & 26.304 & $36.337^{* * *}$ \\
Line & 17 & 0.147 & $5.707^{* * *}$ & 0.352 & $10.356^{* * *}$ & 1.293 & $1.787^{*}$ \\
Error & 87 & 0.026 & & 0.034 & & 0.724 & \\
\hline
\end{tabular}

***, * significant at $p<0.001$ and 0.05 , respectively.

Multivariate PCA analysis showed that the highest FHB resistance explained by eight variables (FHBi, FDKw, yield, TKW, ERG, DON, NIV, and ZEN) was found in resistant wheat lines carrying the Fhb1 gene and in two triticale lines (DS.9 and BOHD 1025-5) (Figure 3). Five other lines had also considerable FHB resistance (BOH 898-1, BOH 534-4, BOH 537-2, MAH 33544-1, and LD 121/08). More susceptible triticale lines showed high kernel damage and toxins accumulation. Susceptible wheat line DL 325/11/3 could be characterised by high Fusarium head blight severity (FHBi) and high ERG concentration.

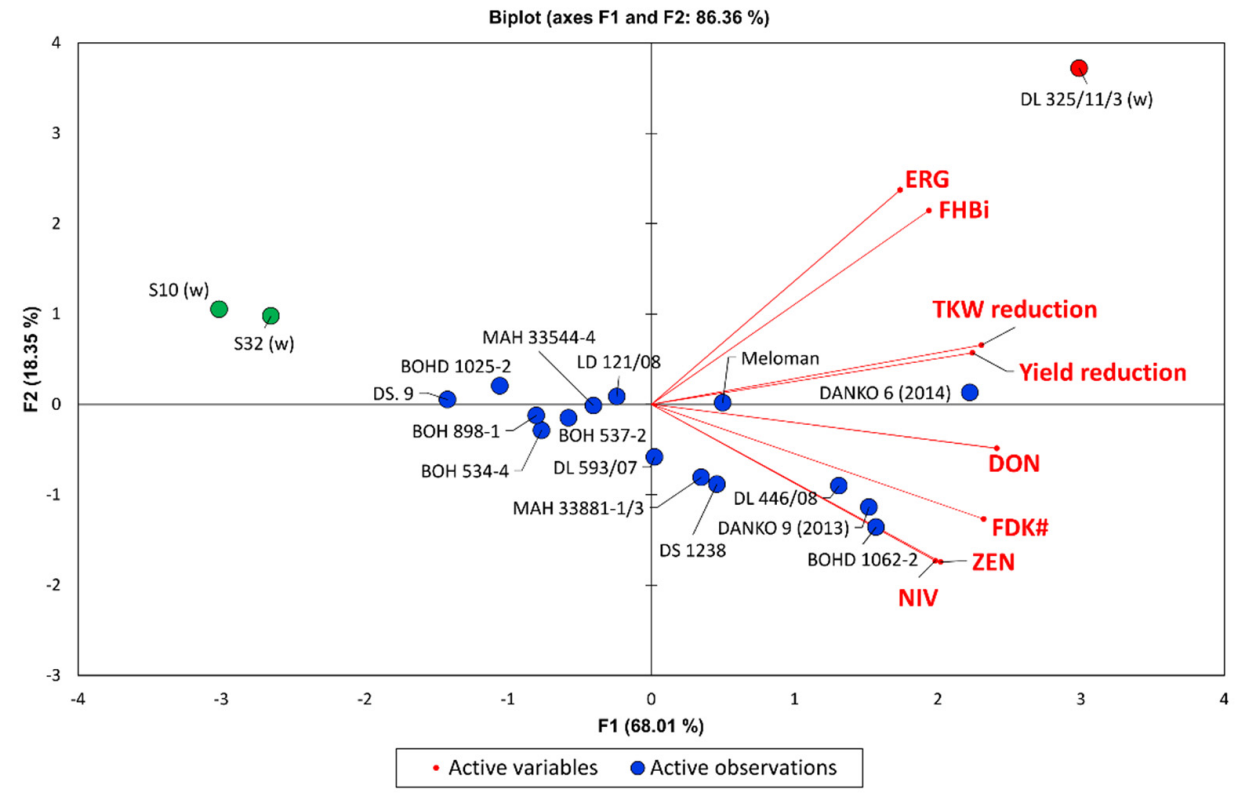

Figure 3. Biplot of principal component analysis (PCA) analysis of FHBi, FDK\#, yield reduction, TKW reduction, ERG, DON, NIV, and ZEN for 15 winter triticale and 3 winter wheat lines (w). 
The number of infection points (measure of type 1 resistance) was on average 1.89 (1.96 for triticale) at a range 1.00 (BOH 898-1, DANKO 9 (2013))-3.40 (BOH 537-2) (Table 9). Lines did not differ statistically significantly for type 1 resistance. However, the lowest type 1 resistance was found for wheat lines and three triticale lines (DS. 9, BOHD 1025-2 and DS 1238). The number of infected spikelets (measure of type 2 resistance) was on average 1.83 (1.84 for triticale) at a range 0.60 (wheat S32)-4.40 (DL 325/11 wheat). For triticale type 2 resistance range was 1.00 (BOH 537-2)-4.00 (DANKO 9 (2013)). Lines differed significantly for type 2 resistance; however, differences between most of the triticale lines were not significant.

Table 9. Type 1 and type 2 resistance to Fusarium head blight of 15 winter triticale and three winter wheat lines.

\begin{tabular}{cccc}
\hline Line & Type $\mathbf{1}^{\mathbf{b}}$ & Type 2 $\mathbf{b}$ & Type 1+2 ${ }^{\mathbf{c}}$ \\
\hline DL 325/11/3 $\mathrm{a}$ & 1.78 & $3.47 \mathrm{a}$ & $2.62 \mathrm{a}$ \\
DANKO 6 (2014) & 2.31 & $2.18 \mathrm{ab}$ & $2.24 \mathrm{ab}$ \\
MAH 33881-1/3 & 2.13 & $2.23 \mathrm{ab}$ & $2.18 \mathrm{abc}$ \\
DANKO 9 (2013) & 1.95 & $2.33 \mathrm{~b}$ & $2.14 \mathrm{abc}$ \\
BOH 534-4 & 2.20 & $2.03 \mathrm{~b}$ & $2.11 \mathrm{abc}$ \\
Meloman & 2.16 & $2.02 \mathrm{~b}$ & $2.09 \mathrm{abc}$ \\
BOHD 898-1 & 1.95 & $2.16 \mathrm{~b}$ & $2.05 \mathrm{abc}$ \\
BOH 537-2 & 2.28 & $1.68 \mathrm{~b}$ & $1.98 \mathrm{bcde}$ \\
LD 121/08 & 2.08 & $1.85 \mathrm{~b}$ & $1.96 \mathrm{abcde}$ \\
DL 593/07 & 2.18 & $1.49 \mathrm{~b}$ & $1.83 \mathrm{bcde}$ \\
BOH 1062-2 & 1.83 & $1.80 \mathrm{~b}$ & $1.81 \mathrm{bcde}$ \\
DL 446/08 & 2.10 & $1.50 \mathrm{bc}$ & $1.80 \mathrm{bcde}$ \\
DS 1238 & 1.65 & $1.80 \mathrm{~b}$ & $1.73 \mathrm{cdef}$ \\
MAH 33544-4 & 1.85 & $1.49 \mathrm{bc}$ & $1.67 \mathrm{bcde}$ \\
BOHD 1025-2 & 1.45 & $1.57 \mathrm{~b}$ & $1.47 \mathrm{defg}$ \\
DS.9 & 1.26 & $0.98 \mathrm{~cd}$ & $1.41 \mathrm{efg}$ \\
S32 & 1.45 & $0.85 \mathrm{~d}$ & $1.22 \mathrm{fg}$ \\
S10 & 1.44 & 1.83 & $1.14 \mathrm{~g}$ \\
\hline Means & 1.89 & 1.86 \\
\hline
\end{tabular}

${ }^{\mathrm{a}}$ wheat; $^{\mathrm{b}}$ average number of Fusarium infected spikelets; ${ }^{\mathrm{c}}$ average of type 1 and type 2 ; means marked with the same letter are not significantly different at $p<0.05$ according to Fisher's LSD test performed on $\log _{10}$ transformed variables; means ranked by type $1+2$.

Average resistance of type 1 and 2 was 1.86 (1.90 for triticale) at a range 1.03 (S10 wheat)-3.35 (BOH 537-2). The lines differed significantly for combined resistance of type 1 and 2. The most resistant were two wheat lines with Fhb1 gene and two triticale lines DS.9 and BOHD 1025-2.

Type 1 and type 2 FHB resistance values were correlated with variables describing FHB resistance under field conditions (FHBi, FDK, ERG, and mycotoxin concentration) (Table 10). Type 1 resistance correlated weakly with type 2 resistance. It did not correlate with FHB index and ERG concentration, however correlated with other variables. The highest were coefficients for DON, FDK\# and FDKw. Type 2 resistance correlated significantly with FHBi and other variables except ERG concentration. The highest were coefficients for FHBi, FDK3, and FDKw. 
Table 10. Coefficients of correlation between type 1 and type resistances and Fusarium head blight index, Fusarium-damaged kernels proportion (weight, number) and concentration of ergosterol and mycotoxins in grain of 15 winter triticale and three winter wheat lines.

\begin{tabular}{cccc}
\hline Variables & Type 1 & Type 2 & Type 1+2 \\
\hline Type 2 & $0.482^{*}$ & & \\
Type $1+2$ & 0.759 & 0.931 & 0.730 \\
FHBi & $0.347^{\mathrm{ns}}$ & 0.748 & 0.788 \\
FDKw & 0.631 & 0.709 & 0.795 \\
FDK\# & 0.633 & 0.725 & 0.249 ns \\
ERG & $0.276^{\mathrm{ns}}$ & $0.151^{\mathrm{ns}}$ & 0.794 \\
DON & $0.662^{*}$ & 0.698 & 0.702 \\
NIV & $0.485^{*}$ & 0.654 & 0.777 \\
TCT B & $0.608^{* *}$ & 0.697 & 0.722 \\
ZEN & $0.540^{* *}$ & 0.679 & \\
\hline
\end{tabular}

Coefficients significant at $p<0.001$, except when marked with ${ }^{*},{ }^{*}$, ns_-significant at $p<0.05,0.01$ or nonsignificant, respectively.

The highest correlation coefficients were found for the combined type 1 and type 2 resistances (Table 10). Similarly, ERG concentration did not correlated with type $1+2$ resistance. The strongest were correlations with FDK\# and FDKw as well as with DON and sum of type B trichothecenes.

Three triticale lines with the highest resistance of both types (1 and 2) showed also high resistance level of different types evaluated under field conditions (DS.9, BOHD 1025-2, MAH 33544-4) (Figure 3).

\section{Discussion}

Due to the increase in crop area and exposure to a variety of pathogens in triticale, there has been a breakdown in crop resistance against fungal diseases $[48,49]$. The most remarkable examples have been powdery mildew and yellow rust [50,51]. Recently, a decrease in triticale resistance to pathogens of the Fusarium genus have been observed. FHB outbreaks in wheat have become more serious and frequent in recent decades, possibly due to the changes in climate and agronomic practices [52]. Globally, FHB causes approximately $10-70 \%$ yield loss in epidemic years [53,54]. Because triticale is consumed mainly by farm animals, it is important to maintain good quality grains, especially in case of detrimental toxin content $[55,56]$.

We identified triticale lines highly resistant to FHB and, in particular, to the accumulation of Fusarium toxins. However, some lines despite their low head infection accumulated considerable amounts of trichothecenes in grain, e.g., DANKO 6 (2014), BOHD 1062-2, DL 446/08, DANKO 9 (2013), and MAH 33881-1/3. All these lines (except MAH 33881-1/3) had high Fusarium kernel damage. We observed this problem previously when comparing wheat and triticale under the same conditions in other inoculation experiments [27]. According to conference presentations by Randhawa et al. (2013) and Langevin (2009) (cited by Randhawa et al. [3]), screening of a large number of triticale accessions resulted in only a few lines with a good level of FHB resistance. Some lines showed higher DON accumulation than expected from low head infection. Langevin et al. (2009) speculated that the higher DON content in triticale grain might be caused by a more fragile pericarp during the initial development of the triticale seed.

Research has shown that environmental conditions significantly affect the development of FHB and the accumulation of toxins in the grain [11,57]. Fusarium head blight severity, kernel damage, and concentration of Fusarium metabolites were significantly affected by the experimental year and the location. This study on resistance to FHB and accumulation of Fusarium toxins was conducted over three years in two locations. To maintain humidity during inoculation and after inoculation, mist irrigation was used in Cerekwica. The infection of heads was similar in Cerekwica and Radzików, but the other parameters examined-percentage of FDK, number and weight of grains per head, and the reduction in 
the yield structure parameters-were much higher in Poznań than in Radzików. Similarly, the amount of toxins: type B trichothecenes and zearalenone was higher in Cerekwica.

Weather conditions in 2016 were similar in Cerekwica and Radzików (Supplementary Materials Table S1). Rainfall before anthesis (May) was low and higher (approximately $50 \%$ ) during and after anthesis (June). This resulted in similar head infections in both locations. Next, in July, rainfall in Cerekwica was much higher than in Radzików which (accompanied by higher temperature) resulted in higher kernel damage in the first location. In addition, toxin accumulation in grain in Cerekwica was higher. In 2017, the weather in May was similar in both locations, and in June, rainfall in Radzików was twice as high as in Cerekwica. This led to a higher head infection in Radzików. Similar to July 2016, rainfall in Cerekwica was double that of Radzików. This caused very high kernel damage in Cerekwica. However, the amounts of trichothecenes in grain in both locations were similar and higher than in 2016. We observed differences in the accumulation of DON and NIV in both locations. DON was mainly found in grain from Radzików and NIV mainly in samples from Cerekwica. Weather in 2018 was unfavourable for FHB development, particularly in Cerekwica. Rainfall in June was low compared to previous years. In both locations, head infection was low, even despite application of mist irrigation in Cerekwica. Kernel damage was lower than in previous years and similar in locations. The same was found for trichothecenes and ZEN. As in 2017, we observed the opposite results for DON and NIV concentrations.

Probably observed differences in accumulation of DON and NIV in two locations were result of competition between isolates of different chemotypes. Competition between F. culmorum and F. graminearum species was described by Van der Ohe and Miedaner [58]. One isolate of F. graminearum was of the NIV chemotype and this isolate showed similar pathogenicity to isolates of the DON chemotype. Mixture of DON+NIV chemotypes had stable pathogenicity (head infection), but varied in mycotoxin production in experimental environments. The NIV chemotype is generally considered less aggressive than DON $(3 \mathrm{ADON}, 15 \mathrm{ADON})$ chemotypes $[59,60]$. Results of our experiments showed that it could produce considerable amounts of NIV even in mixture with a more aggressive isolates of the 3ADON chemotype. However, it occurred only in Cerekwica, where application of mist irrigation created conditions more favourable for FHB development.

Under the above variable conditions, some triticale lines showed stable reactions (i.e., were ranked consistently resistant in all environments) for most variables describing FHB resistance. The most stable were the resistant lines BOHD 1025-5, DS.9 and MAH 33544-4. Line BOH 534-4 had a stable reaction to head infection and accumulation of ERG and trichothecenes (low infection and low accumulation); however, less it was stable as regards kernel damage. Similarly, the BOH 898-1 line was less stable for head infection and kernel damage but stable for low ERG and trichothecenes accumulation.

Selection of FHB-resistant genotypes is more complicated in triticale than in wheat. Frequently Fusarium head infection is lower, but other FHB components are comparable to wheat, which is more susceptible. Low visible head infection can result in significant amounts of infected kernels and accumulation of toxins in grain [61,62]. Studies conducted on triticale lines showed that the assessment of resistance to FHB based only on head infection symptoms was only ineffective for the selection of resistant genotypes [61]. The results may differ in the locations of experiments as can be seen from the significance of the interaction between location $\times$ line. Reliable assessment of FHB resistance has to be associated with the evaluation of kernel damage and the amount of toxins accumulated in the grain. Ollier et al. [63] showed that in triticale, FHB severity symptoms on grain measured digitally as "whitened kernel surface" [64] had higher heritability coefficients than FHB symptoms on heads. This variable highly correlated with the mycotoxin content. We also observed much higher values of coefficients for correlations FDK versus mycotoxins than for FHB index versus mycotoxins.

We found that application of ERG content as a measure of Fusarium colonisation of grain is of limited use. Generally, ERG content weakly correlated with other FHB resistance 
types-lack of correlation with kernel damage was observed. It resulted from the fact that ERG is the compound produced by different fungal species and is no specific for Fusarium genus [34]. Quantitative real time PCR seems to be more suitable for measuring Fusarium colonisation of grain as it is specific at genus and species level $[65,66]$.

The introduction into triticale of genes associated with resistance to FHB is very desirable, although it is difficult due to the complex genome of this cereal. Only a few papers have been published on the genetics of FHB resistance in triticale $[25,67,68]$. In papers by Kalih et al. [25,68], 17 FHB-resistance QTLs were presented including six on the rye chromosomes. The most effective (34\%) was the QTL on chromosome 4R. Dhariwal et al. [67] obtained similar results. Using single nucleotide polymorphism (SNP) genotyping, they identified 17 QTLs explaining more than $10 \%$ of the variability in FHB resistance. Seven of them were located on rye chromosomes ( $4 R, 5 R)$. The highest effect had four QTLs on chromosomes 1A, 2B, 4R, and 5R. Association mapping, carried out on varieties and breeding lines differentiated in origin, allowed the identification of QTLs on chromosomes 2A, 2B, $5 \mathrm{~B}$, and for the first time on $3 \mathrm{R}$, with individual QTLs explaining variability in the range of $0.28-30.23 \%$ [69]. The authors highlight the possibility of increasing triticale resistance to FHB in the early generations using tools proposed by genomics.

Recently, an attempt was made to introduce FHB resistance from the spring wheat line CM-82036 into the triticale varieties [63,70]. The Fhb1 gene was detected and validated in triticale background. Nine triticale lines with very high levels of FHB resistance were identified. QTL analysis of FHB resistance showed the presence of additional loci of resistance on chromosomes $2 \mathrm{~B}, 5 \mathrm{R}$, and 7A. QTL on chromosome $5 \mathrm{R}$ coincided with the location of the dwarfing gene Ddw1. Similar research on the introduction of the Fhb1 gene into triticale was also carried out by the Institute of Plant Genetics group [71].

\section{Conclusions}

We found large variability of reaction of triticale lines to Fusarium head blight. Some of the lines, despite low head infection exhibited significant Fusarium kernel damage and high level of Fusarium toxin accumulation. However, lines combing all types of FHB resistance were identified. Two of them had the highest FHB resistance, however lower than wheat lines with the Fhb1 gene used as a highly resistant control.

Supplementary Materials: The following are available online at https:/ / www.mdpi.com/2073-439 5/11/1/16/s1, Table S1: Air temperature and rainfall in May, June, and July of 2016, 2107, and 2018 in two experimental locations.

Author Contributions: Conceptualization, H.W. and T.G.; methodology, H.W., T.G., and P.O.; validation, T.G.; formal analysis, T.G.; investigation, H.W., T.G., P.O., D.W.-G., and A.T.; resources, H.W., T.G., and P.O.; data curation, H.W., T.G., and P.O.; writing-original draft preparation, H.W. and T.G.; writing-review and editing, H.W., T.G., P.O., D.W.-G., and A.T.; visualization, T.G.; project administration, H.W.; funding acquisition, H.W. All authors have read and agreed to the published version of the manuscript.

Funding: Research was supported by projects from the Ministry of Agriculture and Rural Development: "Evaluation of Fusarium head blight resistance types in winter triticale using phenotypic and metabolic markers", project no. 14, and "Identification, and application of phenotypic, metabolic and molecular markers in studies of types of resistance to Fusarium head blight in winter wheat accessions differing in resistance", project no. 6 (HOR hn 801-PB-13/16, HOR.hn.802.28.2017, HOR.hn.802.19.2018).

Acknowledgments: The Authors wish to thank triticale and wheat breeders from Hodowla Roślin Strzelce Ltd., Co.-IHAR-PIB Group and DANKO Hodowla Roślin Ltd. for providing triticale and wheat lines for the experiment.

Conflicts of Interest: The authors declare no conflict of interest. 


\section{References}

1. Wilson, A.S. On wheat and rye hybrids. Trans. Proc. Bot. Soc. 1876, 12, 286-288. [CrossRef]

2. Mergoum, M.; Singh, P.K.; Peña, R.J.; Lozano-del Río, A.J.; Cooper, K.V.; Salmon, D.F.; Gómez Macpherson, H. Triticale: A "new" crop with old challenges. In Cereals; Springer: New York, NY, USA, 2009; pp. 267-287.

3. Randhawa, H.S.; Bona, L.; Graf, R.J. Triticale breeding-progress and prospect. In Triticale; Springer International Publishing: Cham, Switzerland, 2015; pp. 15-32, ISBN 9783319225517.

4. FAO: Faostat Agricultural Production Data. 2020. Available online: http:/ / faostat.fao.org (accessed on 2 November 2020).

5. Meale, S.J.; McAllister, T.A. Grain for feed and energy. In Triticale; Springer International Publishing: Cham, Switzerland, 2015; pp. 167-187, ISBN 9783319225517.

6. Woś, H.; Brzeziński, W. Triticale for food-The quality driver. In Triticale; Eudes, F., Ed.; Springer International Publishing: Cham, Switzerland, 2015; pp. 213-232, ISBN 9783319225517.

7. Snijders, C.H.A. Fusarium head blight and mycotoxin contamination of wheat, a review. Neth. J. Plant Pathol. 1990, 96, 187-198. [CrossRef]

8. Bottalico, A.; Perrone, G. Toxigenic Fusarium species and mycotoxins associated with head blight in small-grain cereals in Europe. Eur. J. Plant Pathol. 2002, 108, 611-624. [CrossRef]

9. Mesterhazy, A. Types and components of resistance to Fusarium head blight of wheat. Plant Breed. 1995, 114, 377-386. [CrossRef]

10. Miedaner, T. Breeding wheat and rye for resistance to Fusarium diseases. Plant Breed. 1997, 116, 201-220. [CrossRef]

11. Cowger, C.; Patton-Ozkurt, J.; Brown-Guedira, G.; Perugini, L. Post-anthesis moisture increased Fusarium head blight and deoxynivalenol levels in North Carolina winter wheat. Phytopathology 2009, 99, 320-327. [CrossRef]

12. Góral, T.; Walentyn-Góral, D.; Wiśniewska, H. Odporność typu I i II pszenicy i pszenżyta na fuzariozę kłosów. Biul. IHAR 2015 $277,33-46$.

13. Chelkowski, J.; Kaptur, P.; Tomkowiak, M.; Kostecki, M.; Golinski, P.; Ponitka, A.; Slusarkiewicz-Jarzina, A.; Bocianowski, J. Moniliformin accumulation in kernels of triticale accessions inoculated with Fusarium avenaceum in Poland. J. Phytopathol. 2000, 148, 433-439. [CrossRef]

14. Snijders, C.H.A. Resistance in wheat to Fusarium infection and trichothecene formation. Toxicol. Lett. 2004, 153, 37-46. [CrossRef]

15. Wiśniewska, H.; Góral, T.; Ochodzki, P.; Walentyn-Góral, D.; Kwiatek, M.; Majka, M.; Belter, J.; Banaszak, Z.; Pojmaj, M.; Kurleto, D.; et al. Odporność rodów hodowlanych pszenżyta ozimego na infekcje kłosa grzybem Fusarium culmorum. Biul. IHAR 2015, 276, 39-56.

16. Mesterházy, Á. Role of deoxynivalenol in aggressiveness of Fusarium graminearum and F. culmorum and in resistance to Fusarium head blight. Eur. J. Plant Pathol. 2002, 108, 675-684. [CrossRef]

17. Boutigny, A.-L.; Richard-Forget, F.; Barreau, C. Natural mechanisms for cereal resistance to the accumulation of Fusarium trichothecenes. Eur. J. Plant Pathol. 2008, 121, 411-423. [CrossRef]

18. Foroud, N.A.; Eudes, F. Trichothecenes in cereal grains. Int. J. Mol. Sci. 2009, 10, 147-173. [CrossRef] [PubMed]

19. Bai, G.H.; Shaner, G.; Ohm, H. Inheritance of resistance to Fusarium graminearum in wheat. Theor. Appl. Genet. 2000, 100, 1-8. [CrossRef]

20. Buerstmayr, M.; Steiner, B.; Buerstmayr, H. Breeding for Fusarium head blight resistance in wheat-Progress and challenges. Plant Breed. 2019, 139, 429-454. [CrossRef]

21. Chełkowski, J.; Wiśniewska, H.; Adamski, T.; Goliński, P.; Kaczmarek, Z.; Kostecki, M.; Perkowski, J.; Surma, M. Effects of Fusarium culmorum head blight on mycotoxin accumulation and yield traits in barley doubled haploids. J. Phytopathol. 2000, 148, 541-545. [CrossRef]

22. Pirgozliev, S.R.; Edwards, S.G.; Hare, M.C.; Jenkinson, P. Strategies for the control of Fusarium head blight in cereals. Eur. J. Plant Pathol. 2003, 109, 731-742. [CrossRef]

23. Edwards, S.G. Influence of agricultural practices on fusarium infection of cereals and subsequent contamination of grain by trichothecene mycotoxins. Toxicol. Lett. 2004, 153, 29-35. [CrossRef]

24. Yuen, G.Y.; Schoneweis, S.D. Strategies for managing Fusarium head blight and deoxynivalenol accumulation in wheat. Int. J. Food Microbiol. 2007, 119, 126-130. [CrossRef]

25. Kalih, R.; Maurer, H.P.; Miedaner, T. Genetic Architecture of Fusarium Head Blight Resistance in Four Winter Triticale Populations Phytopathology 2015, 105, 334-341. [CrossRef]

26. Del Ponte, E.M.; Fernandes, J.M.C.; Bergstrom, G.C. Influence of growth stage on Fusarium head blight and deoxynivalenol production in wheat. J. Phytopathol. 2007, 155, 577-581. [CrossRef]

27. Góral, T.; Wiśniewska, H.; Ochodzki, P.; Walentyn-Góral, D. Higher Fusarium toxin accumulation in grain of winter triticale lines inoculated with Fusarium culmorum as compared with wheat. Toxins 2016, 8, 301. [CrossRef] [PubMed]

28. Góral, T.; Ochodzki, P. Resistance of Polish winter triticale cultivars to Fusarium head blight and accumulation of Fusariummycotoxins in grain. In Proceedings of the 6th International Triticale Symposium, Stellenbosch, South Africa, 3-7 September 2006; Botes, W.C., Boros, D., Darvey, N., Gustafson, P., Jessop, R., Marais, G.F., Oettler, G., Salmon, D., Eds.; Stellenbosch University: Stellenbosch, South Africa, 2007; pp. 140-143.

29. Gaikpa, D.S.; Lieberherr, B.; Maurer, H.P.; Longin, C.F.H.; Miedaner, T. Comparison of rye, triticale, durum wheat and bread wheat genotypes for Fusarium head blight resistance and deoxynivalenol contamination. Plant Breed. 2019, 139, 251-262. [CrossRef] 
30. Commission Regulation (EC) No 1126/2007 of 28 September 2007 Amending Regulation (EC) No 1881/2006 Setting Maximum Levels for Certain Contaminants in Foodstuffs as Regards Fusarium Toxins in Maize and Maize Products (Text with EEA Relevance). Available online: https:/ / eur-lex.europa.eu/legal-content/EN/ALL/?uri=CELEX:32007R1126 (accessed on 30 November 2020).

31. Commission Recommendation of 17 August 2006 on the Presence of Deoxynivalenol, Zearalenone, Ochratoxin A, T-2 and HT-2 and Fumonisins in Products Intended for Animal Feeding (Text with EEA relevance). Available online: https://eur-lex.europa. eu/legal-content/EN/TXT/?uri=CELEX:32006H0576 (accessed on 30 November 2020).

32. Langevin, F.; Eudes, F.; Comeau, A. Effect of trichothecenes produced by Fusarium graminearum during Fusarium head blight development in six cereal species. Eur. J. Plant Pathol. 2004, 110, 735-746. [CrossRef]

33. Buśko, M.; Góral, T.; Cichy, H.; Matysiak, A.; Perkowski, J. Akumulacja deoksyniwalenolu i ergosterolu w ziarnie pszenżyta porażnym przez Fusarium culmorum. Folia Univ. Agric. Stetin. Agric. 2006, 247, 21-28.

34. Perkowski, J.; Buśko, M.; Stuper, K.; Kostecki, M.; Matysiak, A.; Szwajkowska-Michałek, L. Concentration of ergosterol in small-grained naturally contaminated and inoculated cereals. Biologia 2008, 63, 542-547. [CrossRef]

35. Góral, T.; Wiśniewska, H.; Ochodzki, P.; Walentyn-Góral, D.; Grzeszczak, I.; Belter, J.; Majka, M.; Bogacki, J.; Drzazga, T.; Ługowska, B.; et al. Fuzarioza kłosów oraz akumulacja toksyn fuzaryjnych w ziarnie rodów hodowlanych pszenicy ozimej. Biul. IHAR 2017, 282, 17-40.

36. Góral, T.; Wiśniewska, H.; Walentyn-Góral, D.; Radecka-Janusik, M.; Czembor, P. Resistance to Fusarium head blight [Fusarium culmorum (W.G. Sm.) Sacc.] of winter wheat lines generated from crosses between winter type cultivars and resistant spring wheat Sumai 3. Prog. Plant Prot. 2016, 56, 285-295. [CrossRef]

37. Góral, T.; Wiśniewska, H.; Ochodzki, P.; Walentyn-Góral, D.; Kwiatek, M. Reaction of winter triticale breeding lines to Fusarium head blight and accumulation of Fusarium metabolites in grain in two environments under drought conditions. Cereal Res. Commun. 2013, 41, 106-115. [CrossRef]

38. Lancashire, P.D.; Bleiholder, H.; Van Den Boom, T.; Langeluddeke, P.; Stauss, R.; Weber, E.; Witzenberger, A. A uniform decimal code for growth stages of crops and weeds. Ann. Appl. Biol. 1991, 119, 561-601. [CrossRef]

39. György, A.; Tóth, B.; Varga, M.; Mesterhazy, A. Methodical considerations and resistance evaluation against Fusarium graminearum and F. culmorum head blight in wheat. Part 3. Susceptibility window and resistance expression. Microorganisms $2020,8,627$. [CrossRef] [PubMed]

40. Imathiu, S.; Edwards, S.; Ray, R.; Back, M. Review article: Artificial inoculum and inoculation techniques commonly used in the investigation of Fusarium head blight in cereals. Acta Phytopathol. Entomol. Hung. 2014, 49, 129-139. [CrossRef]

41. Chełkowski, J. Significance of Fusarium metabolites in interaction between a cereal plant and a pathogen. Genet. Pol. 1994, 35B, 137-142.

42. Argyris, J.; Van Sanford, D.; TeKrony, D. Fusarium graminearum infection during wheat seed development and its effect on seed quality. Crop Sci. 2003, 43, 1782-1788. [CrossRef]

43. Góral, T.; Wiśniewska, H.; Ochodzki, P.; Nielsen, L.K.; Walentyn-Góral, D.; Stępień, Ł. Relationship between Fusarium head blight, kernel damage, concentration of Fusarium biomass, and Fusarium toxins in grain of winter wheat inoculated with Fusarium culmorum. Toxins 2019, 11, 2. [CrossRef]

44. Kubo, K.; Kawada, N.; Fujita, M. Evaluation of Fusarium head blight resistance in wheat and the development of a new variety by integrating type I and II resistance. Jpn. Agric. Res. Q. 2013, 47, 9-19. [CrossRef]

45. Patton-Ozkurt, J.; Navarro, R.; Cowger, C. FHB Type I Resistance in Wheat Greenhouse Screening Protocol. Available online: https://scabusa.org/pdfs/ptt/cowger_type1-screening_protocol.pdf (accessed on 2 December 2020).

46. Rudd, J.C.; Horsley, R.D.; McKendry, A.L.; Elias, E.M. Host plant resistance genes for Fusarium head blight. Crop Sci. 2001, 41, 620. [CrossRef]

47. Bai, G. Single Floret Inoculation in Greenhouse. Available online: https://scabusa.org/pdfs/ptt/Bai_Greenhouse-Screening.pdf (accessed on 2 December 2020).

48. Arseniuk, E.; Góral, T. Triticale Biotic Stresses-Known and Novel Foes. In Triticale; Eudes, F., Ed.; Springer International Publishing: Cham, Switzerland, 2015; pp. 1-256, ISBN 9783319225517.

49. Arseniuk, E. Triticale Diseases-A Review. In Triticale: Today and Tomorrow; Guedes-Pinto, H., Darvey, N., Carnide, V.P., Eds.; Springer: Dordrecht, The Netherlands, 1996; pp. 499-525.

50. Hovmøller, M.S.; Walter, S.; Bayles, R.A.; Hubbard, A.; Flath, K.; Sommerfeldt, N.; Leconte, M.; Czembor, P.; Rodriguez-Algaba J.; Thach, T.; et al. Replacement of the European wheat yellow rust population by new races from the centre of diversity in the near-Himalayan region. Plant Pathol. 2015, 65, 402-411. [CrossRef]

51. Walker, A.S.; Bouguennec, A.; Confais, J.; Morgant, G.; Leroux, P. Evidence of host-range expansion from new powdery mildew (Blumeria graminis) infections of triticale ( $\times$ Triticosecale) in France. Plant Pathol. 2011, 60, 207-220. [CrossRef]

52. Yi, X.; Cheng, J.; Jiang, Z.; Hu, W.; Bie, T.; Gao, D.; Li, D.; Wu, R.; Li, Y.; Chen, S.; et al. Genetic analysis of Fusarium head blight resistance in CIMMYT bread wheat line C615 using traditional and conditional QTL mapping. Front. Plant Sci. $2018,9,573$. [CrossRef]

53. Zhang, L.; Luo, P.; Ren, Z.; Zhang, H. Controlling Fusarium head blight of wheat (Triticum aestivum L.) with genetics. Adv. Biosci. Biotechnol. 2011, 2, 263-270. [CrossRef] 
54. Cheng, S.; Zhang, Y.; Bie, T.; Gao, D.; Zhang, B. Damage of wheat Fusarium head blight epidemics and genetic improvement of wheat for scab resistance in China. Jiangsu J. Agric. Sci. 2012, 28, 938-942.

55. Pestka, J.J. Deoxynivalenol: Toxicity, mechanisms and animal health risks. Anim. Feed Sci. Technol. 2007, 137, 283-298. [CrossRef]

56. Zinedine, A.; Soriano, J.M.; Moltó, J.C.; Mañes, J. Review on the toxicity, occurrence, metabolism, detoxification, regulations and intake of zearalenone: An oestrogenic mycotoxin. Food Chem. Toxicol. 2007, 45, 1-18. [CrossRef]

57. West, J.S.; Holdgate, S.; Townsend, J.A.; Edwards, S.G.; Jennings, P.; Fitt, B.D.L. Impacts of changing climate and agronomic factors on Fusarium hear blight of wheat in the UK. Fungal Ecol. 2012, 5, 53-61. [CrossRef]

58. Von der Ohe, C.; Miedaner, T. Competitive aggressiveness in binary mixtures of Fusarium graminearum and F. culmorum isolates inoculated on spring wheat with highly effective resistance QTL. J. Phytopathol. 2010, 159, 401-410. [CrossRef]

59. Liu, Y.Y.; Sun, H.Y.; Li, W.; Xia, Y.L.; Deng, Y.Y.; Zhang, A.X.; Chen, H.G. Fitness of three chemotypes of Fusarium graminearum species complex in major winter wheat-producing areas of China. PLoS ONE 2017, 12, e0174040. [CrossRef]

60. Goswami, R.S.; Kistler, H.C. Pathogenicity and in planta mycotoxin accumulation among members of the Fusarium graminearum species complex on wheat and rice. Phytopathology 2005, 95, 1397-1404. [CrossRef]

61. Miedaner, T.; Kalih, R.; Großmann, M.S.; Maurer, H.P. Correlation between Fusarium head blight severity and DON content in triticale as revealed by phenotypic and molecular data. Plant Breed. 2016, 135, 31-37. [CrossRef]

62. Oettler, G.; Wahle, G. Genotypic and environmental variation of resistance to head blight in triticale inoculated with Fusarium culmorum. Plant Breed. 2001, 120, 297-300. [CrossRef]

63. Ollier, M.; Talle, V.; Brisset, A.L.; Le Bihan, Z.; Duerr, S.; Lemmens, M.; Goudemand, E.; Robert, O.; Hilbert, J.L.; Buerstmayr, H. QTL mapping and successful introgression of the spring wheat-derived QTL Fhb1 for Fusarium head blight resistance in three European triticale populations. Theor. Appl. Genet. 2020, 133, 457-477. [CrossRef] [PubMed]

64. Ollier, M.; Talle, V.; Brisset, A.-L.; Le Bihan, Z.; Duerr, S.; Lemmens, M.; Goudemand, E.; Robert, O.; Hilbert, J.-L.; Buerstmayr, H. Whitened kernel surface: A fast and reliable method for assessing Fusarium severity on cereal grains by digital picture analysis. Plant Breed. 2018, 138, 69-81. [CrossRef]

65. Edwards, S.G.; O'Callaghan, J.; Dobson, A.D.W. PCR-based detection and quantification of mycotoxigenic fungi. Mycol. Res. 2002, 106, 1005-1025. [CrossRef]

66. Kumar, A.; Karre, S.; Dhokane, D.; Kage, U.; Hukkeri, S.; Kushalappa, A.C. Real-time quantitative PCR based method for the quantification of fungal biomass to discriminate quantitative resistance in barley and wheat genotypes to Fusarium head blight. J. Cereal Sci. 2015, 64, 16-22. [CrossRef]

67. Dhariwal, R.; Fedak, G.; Dion, Y.; Pozniak, C.; Laroche, A.; Eudes, F.; Randhawa, H.S. High density single nucleotide polymorphism (SNP) mapping and quantitative trait loci (QTL) analysis in a biparental spring triticale population localized major and minor effect Fusarium head blight resistance and associated traits QTL. Genes 2018, 9, 19. [CrossRef]

68. Kalih, R.; Maurer, H.P.; Hackauf, B.; Miedaner, T. Effect of a rye dwarfing gene on plant height, heading stage, and Fusarium head blight in triticale (×Triticosecale Wittmack). Theor. Appl. Genet. 2014, 127, 1527-1536. [CrossRef]

69. Galiano-Carneiro, A.L.; Boeven, P.H.G.; Maurer, H.P.; Würschum, T.; Miedaner, T. Genome-wide association study for an efficient selection of Fusarium head blight resistance in winter triticale. Euphytica 2019, 215, 4. [CrossRef]

70. Buerstmayr, H.; Lemmens, M.; Hartl, L.; Doldi, L.; Steiner, B.; Stierschneider, M.; Ruckenbauer, P. Molecular mapping of QTLs for Fusarium head blight resistance in spring wheat. I. Resistance to fungal spread (type II resistance). Theor. Appl. Genet. 2002, 104, 84-91. [CrossRef]

71. Wiśniewska, H.; Góral, T.; Ochodzki, P.; Majka, M.; Walentyn-Góral, D.; Belter, J. Badanie typów odporności na fuzariozę kłosów u pszenżyta ozimego za pomocą markerów fenotypowych i metabolicznych. Biul. Inst. Hod. Aklim. Roślin 2019, 286, 75-79. [CrossRef] 